\title{
SUBHİ EZEL MİRZA YAHYA VE EZELİLER
}

\author{
Yasin IPEKa
}

Öz

Beklenen kurtarıcı fikri inanç sistemlerinin çoğunda mevcuttur. İslamiyet içerisinde de özellikle Şii anlayışta hâkim olan bu beklenti birçok yeni dini akımın doğmasına sebep olmuştur. Bunlardan biri de Babîliktir. Mirza Ali Muhammed'in Şiilerin gelişini bekledikleri kurtarıcıya açılan kapı (Bab) olduğu iddiasıyla Mayıs 1844 'te ortaya çıkması Babîliğin de başlangıcıdır. Kısa sürede etrafına çok sayıda insan toplamayı başaran Bab gerek söylemlerinden gerekse taraftarlarının saldırgan tutumlarından dolayı Kaçar yöneticilerini rahatsız etmiş ve neticede tutuklanmış ve idam edilmiştir.

Bab, idam edilmeden önce kendisine ilk tabii olanlardan Mirza Yahya adındaki genci vekili olarak ilan etmiş̦tir. Mirza Yahya'nın vekilliğine ilk ve en büyük tepkiyi gösteren kiși kardeşi Mirza Hüseyin Ali olmuştur. Her iki grup da karşı tarafı sahtekarlıkla suçlayıp gerçek vekilin kendisi olduğunu iddia etmiştir. İki kardeş arasındaki bu çekişme zamanla Babîlere de sirayet etmiş ve Babî toplumu üç gruba ayrılmıștır: Bir tarafta "Subhi Ezel" lakabıyla anılan alan Mirza Yahya'yı haklı görüp onun yanında yer alan "Ezeliler", bir tarafta "Bahaullah" lakabıyla anılan Mirza Hüseyin Ali'yi halkı görüp onun yanında yer alan "Bahailer", bir tarafta da iki kardeşin de kendi çıkarlarına Bab'ı alet ettiğini düşünen ve kimseye bağlı olmayan "Beyaniler" yer almıştır. Bu üç Babî grup içerisinde öze en bağlı olduklarını iddia eden Ezeliler, günümüzde en iyimser tahminle beş bin civarında bir nüfusa sahiptir ve bunların büyük bir kısmı İran'da yaşamaktadır.

Kendilerine has inanç, ibadet ve ahlak ilkeleri olan Ezeliler bu ilkelerin esaslarını, Bab'a vahyedildiğine inandıkları "Beyan" kitabından almaktadırlar. Ayrıca Subhi Ezel tarafından kaleme alınan ve ona Allah tarafından yazdırıldığına inandıkları eserleri de "Beyan"ın bir nevi tefsiri olarak kabul etmekte ve kutsal saymaktadırlar.

Anahtar kelimeler: Dinler Tarihi, Subhi Ezel, Babîler, Ezeliler, Bahailer.

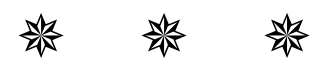

a Dr. Öğr. Üyesi, Kayseri Üniversitesi, yasinipek@kayseri.edu.tr 


\section{SUBHI AZAL MIRZA YAHYA AND THE AZALIS}

Mirza Ali Muhammad's appearance in May 1844, claiming that the Shia's were waiting for the arrival of the Door (Bab), is also the beginning of Babism. Prior to his execution, Bab declared a young man named Mirza Yahya who was one of the first of his subjects, as his deputy. Spread to the Babis, and the Babi society was divided into three groups: On one side were "Azalis" who declared "Subhi Ezel" Mirza Yahya as right and stood next to him", on the other side were Bahais who accepts "Bahaullah" Mirza Husayn Ali as righteous and stood by him and on the third side were "Beyanis" who believed that both brothers had used Bab in their own interests and who were not affiliated with anyone. Among these three Babi groups, the Azalis, who claim to be the most connected to the essence, today have a population of about five thousand people by the most optimistic estimate, and most of them live in Iran.

Azalis, who have their own principles of faith, worship and morality, take the foundations of these principles from the book of "Bayan", which they believe having been revealed to Bab. They also accept the works written by Subhi Azal, which they believed being made written by Allah, as a kind of exegesis of the "Beyan" and consider them as sacred.

[The Extended Abstract is at the end of the article.]

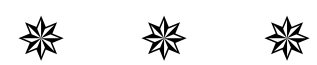

\section{Giriş}

İnsanlık tarihi boyunca birçok din ve dini akım ortaya çıkmıştır. Bunların büyük çoğunluğunun doğduğu ve yayıldığı yer Ortadoğu'dur. Bu bölgenin en önemli merkezlerinden biri ise İran olmuştur. Gerek jeopolitik konumu gerekse zengin yer altı ve yer üstü kaynaklarından dolayı tarih boyunca birçok uygarlığa ve inanca ev sahipliği yapmıştır. İran coğrafyası, Kaçarlar döneminde (1795- 1925) hem Şii İslam'ın merkezi hem de Babîlik gibi yeni dini akımların çıkış noktası olmuştur.

On dokuzuncu yüzyılın ortalarında Şii İslam anlayışının hâkim olduğu İran coğrafyasında ortaya çıkan Babîlik, başlangıçta İslami kimlikli dini bir hareket iken zamanla bu çizgisinden uzaklaşmış, Ezelilik ve Bahailik gibi müstakil dini oluşumlara dönüşmüştür. Bab Mirza Ali Muhammed'in kurucusu olduğu bu yeni dini oluşumlardan Babîlik ve Bahailik hakkında birçok çalışma yapılmış olmasına rağmen Ezelilik konusunda ülkemizde bir çalışma yapılmamış, yurt dışında da az sayıda eser yayınlanmıştır. Bu sebeple hem mevcut bilgi eksikliğinin giderilmesine katkıda bulunmak hem de konuya ilişkin derli toplu bir çalışma ortaya koyak adına hazırlanan bu çalışmanın alandaki bir boşluğu dolduracağı düşünülmektedir. Bu çalışmada 
öncelikle Bab Mirza Ali Muhammed ve Babîlik hakkında kısa bir bilgi verilecek ardından da Mirza Yahya'nın Subhi Ezel olarak orta çıkışı ve Ezeliliğin teşekkülü konuları işlenecektir.

Babîliğin kurucusu olan Bab lakaplı Mirza Ali Muhammed'in 1844 yılında Şii İslam anlayışına hâkim olan beklenen zuhurun yaklaștığını ve kendisinin de o zuhurun kapısı (Bab) olduğunu ilan etmesiyle Babîlik tarih sahnesine çıkmıștır. Ahir zamanda gelecek bir kurtarıcı fikri zamanla İslami söylemden uzaklaşıp tüm insanlığı kapsayan yeni bir şeriat ve yeni bir peygamber inancına dönüşmüştür. Ortaya çıkan bu dinin adı Babîlik, peygamberi ise Bab Mirza Ali Muhammed olarak kabul edilmiștir. Onun ölümden sonra Bab'ın vekili ve Babîlerin liderinin kim olacağı tartışması başlamış ve iki kardeş ön plana çıkmıştır. Bunlar, Subhi Ezel Mirza Yahya ${ }^{1}$ ile kardeşi Bahaullah Mirza Hüseyin Ali2'dir. Bu iki kardeş arasındaki çekişme onların ölümleri sonrasında taraftarların arasında da devam etmiştir.

İnanç ve ibadet esaslarının Bab Mirza Ali Muhammed'in öğretilerine göre temellendirildiği söyleyen Ezeliler, başlangıçta İslami bir görüntü arz ederken zaman içerisinde Bab'ın kimliği ve söylemleri doğrultusunda İslam dışı bir dini harekete dönüşmüşlerdir. Bu oluşumun başlangıç noktası Subhi Ezel Mirza Yahya'nın Bab'ın tayin ettiği vekilin kendisi olduğu iddiasıyla ortaya çıkmasıdır. Bunu kardeși Bahaullah Mirza Hüseyin Ali ile mücadelesi izlemiş ve neticede Babîler; Babî (Beyani), Ezeli ve Bahai şeklinde bölünmüşlerdir. Yani Ezelilik, Subhi Ezel önderliğinde yeniden şekillenen Babîliğin son halidir. Bu noktada Ezeliliği anlayabilmek için öncelikle Bab ve Babîlik hakkında bilgi vermek faydalı olacaktır.

Taraftarlarınca "Bab" olarak kabul edilen Mirza Ali Muhammed, Babî olmayanlara göre; başlangıçta Şiilerin beklediği "Gaib İmam’a Açlan Kapı (Bab)" olduğu iddiasıyla ortaya çıkmıştır. Zaman içerisinde etrafındaki insanların artmasıyla doğru orantılı olarak sırasıyla "Mehdi", ardından da kitap indirilmiş "Peygamber" olduğunu iddia etmiştir. Son olarak da iddialarını daha da ileri götürerek kendisini Allah'ın tüm sıfatlarının zatıyla yansıdığı bir ayna olarak görmüş ve Tanrılık iddiasında bulunmuştur. ${ }^{3}$

\footnotetext{
1 Bu çalışmada Mirza Yahya'dan; Bab Mirza Ali Muhammed tarafından vekil ilan edildiği Mart 1850 tarihe kadar "Mirza Yahya", bu tarihten sonra da "Subhi Ezel" olarak bahsedilmiştir.

2 Bu çalışmada Mirza Hüseyin Ali'den; Mart 1868'da Edirne'de “Emir"ini resmen ilan ettiği tarihe kadar "Mirza Hüseyin Ali", bu tarihten sonra da "Bahaullah" olarak bahsedilmiștir. 3 Ethem Ruhi Fığlalı, Babilik ve Bahailik (Ankara: Türkiye Diyanet Vakfı Yayınları, 1994), 30
} 
Kısacası o, İslam akaidini inkâr etmiş biridir. ${ }^{4}$

Babîlere göreyse (Ezeli ve Bahaileri de bu gruba dahil edebiliriz) o ; Allah tarafından geleceği müjdelenen ve vaat edilen, Allah'ın siması, vahiy alan hatta Kur'an'daki ayet sayısı kadar ayeti iki gecede indirebilen ve Kur'an'ın devrini kapatma hakkının sahibi, Allah adına konuşma yetkisi olan, İslam şeriatının hükümlerini neshedip yeni bir dinin haberini veren, hakkında geçmiş tüm peygamberlerle ahitleşilen ve hepsinin alametlerini kendisinde bulunduran, Sünni Müslümanların beklediği "Mesih", Şii Müslümanların beklediği "Vaat Edilen Kişi", Hıristiyanların beklediği "Vaftizci Yahya”, Yahudilerin beklediği “İlya”, Zerdüştlerin beklediği “Uşidar Mah" tır. ${ }^{5}$

Bab Mirza Ali Muhammed'in yazmış olduğu çok sayıda eserden en dikkat çekeni, Babîlerin Kur'an-ı Kerim'i olarak ifade edilen kitabı "Beyan"dır. Arapça ve Farsça yazılmış olan "Beyan"ın Bab'a, Makü ve Çehrik'te mahkûm olduğu dönemlerde vahyedildiği iddia edilmektedir. On bir bölümden oluşan bu kitapta birçok konuya değinilmiş olmasına rağmen asıl olarak yeni dinin esaslarından ve Tanrı'nın zuhur edeceği kişinin özelliklerinden bahsedilmektedir. ${ }^{6}$ Subhi Ezel Mirza Yahya ve Ezelilerin de çıkış noktası burasıdır.

\section{A. Subhi Ezel Mirza Yahya (1831- Nisan 1912)}

Çalışmamızın asıl öznesi olan Subhi Ezel Mirza Yahya'nın hayatını ele alacağımız bu bölümde detaylı bir tarihçeye yer vereceğiz. Çünkü Ezeliliğin teşekkülünün daha iyi anlaşılabilmesi için Bab sonrası dönemde Babîlerin durumunun net şekilde anlaşılması gereklidir. Özellikle Bab tarafından vekili olarak Subhi Ezel'in tayin edilmesi ve sonrasında kardeşi Bahaullah ile olan iktidar mücadeleleri anlaşılmadığı takdirde bu dini oluşumun iddia ve söylemleri bir temelden yoksun kalacaktır.

\section{Mirza Yahya'nın Hayatı ve Ezeliliğin Teşekkülü}

Mirza Yahya Nuri, 1831 yılında İran'ın Tahran şehrinde doğmuştur. Ata memleketi Mazenderan eyaletinin Nur şehrine bağlı Takur köyüdür. Babası dönemim önemli Kaçar bürokratlarından birisi olan Mirza Abbas

\footnotetext{
4 Yılmaz Karadeniz, İran'da Sömürgecilik Mücadelesi ve Kaçar Hanedanı (İstanbul: Bakış Yayınları, 2006), 179-180.

5 Jalal S. Azal, The Religion of The Bayan and The Claims of The Baha'is (PDF: Bayanic Digital Publications, January 2004), 46; Adip Taherzadeh, Hz. Bahaullah'ın Zuhuru, çev. Süreyya Güler (İstanbul: Kazancı Matbaacılık, 1995), 1/300.

6 Şevki Efendi, Bahai Dininin I. Yüzyılı, çev. Suna Bozkır (İstanbul: Baha Yayınları, 1995), 25.
} 
Buzurg Nuri, annesi ise Küçük Hanım Kirmanşahi'dir.7 Toplam on yedi kardeşe sahip olan Mirza Yahya'nın anne ve baba bir kardeşleri: Sarih Hanım, Mirza Mehdi, Mirza Musa, Nisa Hanım; anne bir kardeşleri ise: Mirza Muhammed Ali, Sakine Hanım (Zallan Hanım), Sughra (Sukra) Hanım'dır. Aralarında Bahailiğin kurucusu olan ve ileride en büyük rakibi olacak olan kendisinden on üç yaş büyük abisi Mirza Hüseyin Ali'nin (Bahaullah) de olduğu baba bir kardeşleri ise: Mirza Ağa, Mirza Muhammed Hasan, Şah Sultan Hanım (Hanım Buzurg/ İzziye Hanım), Mirza Taki, Mirza Rıza Kuli (Doktor), Mirza İbrahim, Fatma Sultan, Mirza Muhammed Kuli, Hüsniye Hanım'dır. İleride yaşanacak Babîlerin liderliği mücadelesinde tüm bu kardeșleri arasından sadece Şah Sultan Hanım, Mirza Taki ve Fatma Sultan; Mirza Yahya'nın yanında yer alarak "Ezeli" olmuşlardır. ${ }^{8}$

Kaçar sarayında yetkili bir bürokrat ve Tahran'daki varlıklı insanlardan bir olan Mirza Abbas Buzurg, Kaçar Hükümdarı Muhammed Şah'ın kızıyla olan gönül ilişkisinin açığa çıkması üzerine görevinden uzaklaştırılmış ve tüm mal varlığına el konulmuştur. Birdenbire her şeyini kaybetmenin üzüntüsüne dayanamayan Buzurg, 1834'te vefat etmiştir. Annesi Küçük Hanım'ı da kendisini doğururken kaybeden Mirza Yahya'ya artık üvey annesi Hatice Hanım (Bahaullah'ın öz annesi) bakmaya başlamıştır. Başlangıçta hiç ilgilenmediği dört yaşındaki bu çocukla ilgili bir rüyasında; Hz. Muhammed, Hz. Ali ve kızı Fatma'nın bu çocuğu sevip okşadıkların ve beklenen zuhur ortaya çıkana kadar o çocuğa çok iyi bakmasını istediklerini görür. Bu rüya üzerine kendi evlatlarından daha fazla onunla alakadar olmaya başlar. ${ }^{9}$

\section{a. Mirza Yahya'nın Babî Oluşu ve Bab Tarafından Subhi Ezel Olarak Tayin Edilmesi}

23 Mayıs 1844'te Şiraz'da kendisinin "Hakikate Açılan Kapı (Bab)" olduğunu iddia eden Mirza Ali Muhammed'e aynı yıl çerisinde tabii olan Mirza Yahya, ilk Babîlerden kabul edilir. Henüz on üç yaşında olan Mirza Yahya'nın Bab'a inanan üçüncü insan ve "Hurufu Hay"ın (Diri Harfler)

\footnotetext{
7 Nigel Bufton, Mirza Abbas Buzurg Nuri (Or Yehuda: MyHeritage Company, 2008), 10; David V. Barret, The New Believers (London: Cassell \& Co, 2001), 373.

${ }^{8}$ Edward G. Browne, Materials for the Study of the Babi Religion (Cambridge: Cambridge University Press, 1918), 320; Azal, The Religion of The Bayan and The Claims of The Baha'is, 123; Atiyya Ruhi, "A Brief Biography of His Holiness Subh-i Azal”, Bayanic (Erişim 10 Mayıs 2021).

${ }^{9}$ Ruhi, "A Brief Biography of His Holiness Subh-i Azal”; Azal, The Religion of The Bayan and The Claims of The Baha'is, 124,128.
} 
dördüncüsü olduğu da iddia edilmektedir. ${ }^{10}$ Onun küçük yaşına rağmen kendisinden yaşça daha büyük olan Babîlerle bir araya gelerek Bab'ın gönderdiği mektuplar üzerine dersler verdiği söylenir. Sonrasında da hem kendini geliştirmek hem de Bab'a ilk inanan kişi olan "Babul Bab" lakaplı Molla Hüseyin Buşriye ve diğer Babîlerle tanışmak için Horasan'a gider. ${ }^{11}$ 1848 yılında önde gelen Babîlerden Kurretul Ayn ve Kuddüs ile tanışan Mirza Yahya, onlarla birlikte Nur ve Berfuruş şehirlerine giderek üç gün boyunca Babîlik propagandası yapar. ${ }^{12}$

Söylem ve faaliyetlerinden dolayı Bab'ın 1845 yılında Şiraz'da tutuklanması ve sonrasında da Makü (1847) ve Çehrik (1848- 1850) Kalelerine sürgünüyle devam eden süreçte Babiler, çıkardıkları olaylar sebebiyle Kaçar idarecileri ve İran halkı arasında büyük rahatsızlıklara sebep olurlar. Kaçar ordusunun devreye girmesi üzerine ülkenin birçok şehrinde Babîlerle çatışmalar yaşanır ve onlardan bir kısmı Mazenderan yakınlarındaki Şeyh Tabersi Kalesi'ne sığınmak zorunda kalırlar. Aralık 1848'de Mirza Yahya ve Mirza Hüseyin Ali'nin de aralarında bulunduğu bir grup Babî, Şeyh Tabersi Kalesi'ndeki Babîlere gizlice erzak ve mühimmat götürürken Kaçar askerleri tarafından kuşatılırlar. Bu baskından ormana kaçıp kurtulan Mirza Yahya, Amul şehrine geldiğinde yakalanır ve diğer Babî tutsakların yanına gönderilir. Fakat o ve kardeşi Mirza Hüseyin Ali saygın bir ailenin üyeleri oldukları için kısa süren bir gözaltından sonra kaleye bir daha gitmemeleri ve oradaki isyancı Babîlerle irtibatlarını kesmeleri şartıyla serbest birakılırlar. ${ }^{13}$

Bunun üzerine Mirza Yahya, memleketi olan Nur'a dönüp babasından miras kalan evde yaşamaya başlar. Bu esnada hem o bölgedeki Babîlerle irtibatını sürdürür hem de gizlice Babîlik propagandası yapmaya devam eder ve sonrasında Tahran'a gider. Burada Babul Bab'ın ve Kuddüs'ün de aralarında olduğu çok sayıda Babînin Kaçar askerleriyle girdikleri çatışmalarda öldürüldükleri haberlerini alır. Bu gelişmelerden dolayı hem üzülür hem de aynı şeylerin kendi başına da gelme ihtimalinden dolayı telaşa

10 Paul Carus, "A New Religion. Babism", The Open Court (Chicago: The Open Court Publishing, 1904), 13/359.

11 Browne, $A$ Traveller's Narrative, XVI,374; Ruhi, "A Brief Biography of His Holiness Subhi Azal".

12 Jani Kashani, Kitab-i Nuqtat al-Kaf: Being the Earliest History of The Babis, ed. Edward G. Browne (Leiden: E. J. Brill, 1910), 241; Azal, The Religion of The Bayan and The Claims of The Baha'is, 125.

|48| 13 SSevki Efendi, Bahai Dininin I. Yüzyılı, 40-41; Moojan Momen, "Mirza Yahya”, The Bahai Encyclopedia (Evanston: National Spiritual Assembly of The Baha'is of The United States Publishing, 2009). 
kapılır. ${ }^{14}$

Dışarıda bunlar yaşanırken hapishanede olan Bab, Babîlerin sebep olduğu ve İran'ın geneline yayılmaya başlayan olaylardan haberdar olur. Babîlerin başsız kalıp dağılmamaları ve ümitsizliğe düşmemeleri için hem kendisine vekil hem de Babîlere bir lider seçmesi gerektiğini fark eder. Bu görev için de en uygun kişinin henüz on sekizli yaşlardaki Mirza Yahya olduğuna karar verir. 1850 yılı Nevruz'unun yirmi beşinci gününde Mirza Yahya'nın kendisinin vekili olduğunu ilan eder ve kendisine nasıl itaat ediliyorsa ona da aynı şekilde itaat edilmesini ister. Sonrasında Bab, tüm mesajlarını Mirza Yahya'ya bildirmeye başlar. Yazdığı mektuplarda Mirza Yahya'nın kendisi ve Babî inancı için ne kadar önemli olduğunu belirtir. Genellikle Mirza Yahya için "Ezel (Öncesiz)”, "Nukta-i Hani (İkinci Nokta)”, "Tamarayı Ezeliyye (Ezelin Meyvesi)", "Tamarayı Beyan (Beyan Meyvesi)", "Vahid (Bir)", "Hayy (Hayatta Olan)", "Vajh (Tanrı'nın Yüzü)”, "Miratul Ezeliyye (Ezelin Aynası)”, "Behaullah (Tanrı'nın İhtişamı)”, "Bellur (Kristal)”, "İsmul Ezel (Ezel İsmi)”, “Cevheri Kafur (Tanrı Kokusunun Özü)”, "Şemsi Ezel (Ezel Güneşi)", "İsmul Azam (En Yüce İsim)” ve "Subhi Ezel (Öncesi Olmayan Sabah/ Ezel Sabahı)" lakaplarıyla hitap eder. Birçok unvan arasından Mirza Yahya "Subhi Ezel" lakabını kullanmayı tercih eder. ${ }^{15}$ Bu lakabı seçmesinin sebebi olarak da Hz. Ali'nin "Hakikat, ezel sabahından (subhi ezel) parlayan bir ışılktır ki onun ışığı da Allah'ın birliğine delil olan kimselere vurur." sözüne atıfta bulunur ve cümlede bahsi geçen hakikat nurunun kendisi olduğunu iddia eder. ${ }^{16}$ Bundan sonra Babîlerden de kendisine "Subhi Ezel" diye hitap etmelerini ister. ${ }^{17}$

Bundan sonraki süreçte Subhi Ezel lakabıyla faaliyetlerini sürdürecek olan Mirza Yahya, Şiiliğin takiyye anlayışının da etkisiyle, sıkıntılı gördüğü her durumda kendisini gizlemiş ve geriye çekmiştir. ${ }^{18}$ Nihayetinde Temmuz 1850'de Bab'ın idam edilmesinin ardından Subhi Ezel, onun ortada kalan naaşını kendilerine teslim etmesi için Kaçar ordusunda görevli Mirza

14 Ruhi, "A Brief Biography of His Holiness Subh-i Azal”.

15 Carus, "A New Religion. Babism”, 359; Browne, A Traveller's Narrative, 353; Momen, "Mirza Yahya".

${ }^{16}$ Azal, The Religion of The Bayan and The Claims of The Baha'is, 124-126; Ruhi Fığlalı ve Ramazan Şimşek, "Bahailik ve El-Kitabu'l-Akdes (Türkçe Çeviri)”, e-makalat Mezhep Araștırmaları, Cilt 3, Sayı 2 (2010), s. 25.

${ }^{17}$ Bab, ayrıca Mirza Hüseyin Ali'ye de bir mektup yazarak vekilinin Mirza Yahya olduğunu haber vermiş ve ondan kardeşini korumasını istemiştir. Ayrıntılı bilgi için bkz. Ruhi, "A Brief Biography of His Holiness Subh-i Azal".

18 Sepehr Manuchehri, "The Primal Point's Will and Testament", Research Notes in Shaykhi, Babi and Bahai Studies 7/2 (September 2004); Denis Maceoin, "Divisions and Authority Claims in Babism (1850-1866)", Studia Iranica 18/1 (1989), 108. 
Yasin IPEK

Süleyman adlı bir bir askere rüşvet vererek Bab'ın cesedini oradan alıp Tahran'a götürerek "Masum İmamzade Türbesi” ne defneder. ${ }^{19}$

Bab'ın idam edilmesinin ardından Subhi Ezel, baba memleketi olan Takur köyüne yerleşir ve 1852'de evlenir. Bu sırada da boş durmayan Subhi Ezel'in kışları Mazenderan, yazları ise Tahran ve Şimran bölgelerinde Babîliği yaymaya çalıştığı görülür. Bu esnada Kaçar Hükümdarı Nasıruddin Şah, Emir Kebir lakaplı Mirza Taki Han'ı sadrazam olarak atar. Mirza Taki ile geçmişten kalma dostluğu olan ve onun Babîlere karşı ılımlı olduğunu hatırlayan Subhi Ezel için bu gelişme çok sevindirici olmuştur. Fakat Sadrazam göreve başlar başlamaz Subhi Ezel'e bir elçi gönderir ve eğer karşısına çıkarsa en ağır şekilde onu cezalandıracağını bildirir. Aldığı bu haber karşında Subhi Ezel şaşkına döner. Bu esnada bir de bazı Babîlerin Kaçar Hükümdarına suikast düzenleyecekleri haberini alınca hem Sadrazam'ın tehdidinden uzaklaşmak hem bu girişimin amacına ulaşması durumunda ortaya çıkacak yeni yapılanmada yerini almak için etrafına topladığı Babîlerle birlikte ata yurdundan ayrılır. Başarısızlıkla sonuçlanan suikast girişiminin failleri arasında oldukları söylentileri neticesinde Babîlere karşı ülkede genelinde yeniden baskılar başlar. Durumun kötüye gittiğini gören Subhi Ezel tekrar geri plana çekilir ve 1854 yılına kadar gizlenir. Bu iki yıllık zaman diliminde gerçek kimliğini gizleyen Subhi Ezel, bir süre Mazenderan Dağlarında derviş kılığında dolaşır, ardından da misyoner amaçlı olarak Reşt, Kazvin ve Kirmanşah'a gider. ${ }^{20}$

Bu dönemde büyük maddi sıkıntı da çekmeye başlayan Subhi Ezel, kardeşi Mirza Muhammed Hasan'la birlikte amcaları Şeyh Azizullah'tan babalarından kendilerine kalan mirası isterler. Çıkan tartışmada amcalarını darbederler. Şikâyetçi olmak için Tahran'a giden Şeyh Azizullah, bu esnada Babîlerin Kaçar hükümdarı Nasıruddin Şah'a suikast düzenlediklerini duyunca yeğenleri Subhi Ezel ve Mirza Hüseyin Ali'nin de bu olayın planlayıcılarından olduğuna dair ihbarda bulunur. ${ }^{21} \mathrm{Bu}$ ihbara ek olarak 1845'lerden beri Babîlerin ülkede sebep oldukları olay ve karıșıklar, halkın bunların söylemlerinden duyduğu büyük rahatsızlık ve son olarak Şah'a suikast düzenleyecek kadar ileri gitmeleri üzerine Kaçar yönetimi bunları

\footnotetext{
${ }^{19}$ Ruhi, "A Brief Biography of His Holiness Subh-i Azal”. Bab'ın türbesi bu olaydan 18 sene Bahaullah'ın talimatıyla buradan kaçırılarak Akka'ya taşınmıştır. Ayrıntılı bilgi için bk. Yasin İpek, Yeni Bir Dini Hareket Olarak Bahailik ve Türkiye'de Bahailer (Kayseri: Kimlik Yayınları, 2020), 103-104.

20 Taherzadeh, Hz. Bahaullah'ın Zuhuru, 1/51-53; Browne, A Traveller's Narrative, 374; Azal, The Religion of The Bayan and The Claims of The Baha'is, 157.

${ }^{21}$ Ruhi, "A Brief Biography of His Holiness Subh-i Azal".
} 
ülkeden uzaklaştırmaya karar verir. Yapılan tahkikat neticesinde Subhi Ezel'in yaşanan olaylarla doğrudan bir alakası bulunamaz. Kardeși Mirza Hüseyin Ali'nin ise bizzat olayın planlayıcılarından biri olduğu tespit edilir ve tutuklanmasına karar verilir. Fakat Rusların yoğun diplomatik baskıları neticesinde başta Mirza Hüseyin Ali olmak üzere suçlu görülen Babîlerin tutukluluğu kısa sürünce Kaçar idarecileri başka çözümler aramaya koyulurlar. Babîlerin sebep olduğu olaylardan ve bunların yüzünden Rusya ve İngiltere gibi devletlerin sürekli ülkenin iç işlerine karışmasından rahatsız olan Kaçarlar, sıkıntılı gördükleri Babîlerin tamamını sınır dışı etmeye niyetlenirler. Komşu Osmanlı Devleti ile yapılan görüşmeler neticesinde Aralık 1852'de Babîlerin Osmanlı toprağı olan Bağdat'a sürgün edilmesine karar verilir. ${ }^{22}$

\section{b. Bağdat Sürgünü ve Babî Toplumundaki İlk Çatlak}

Sürgün listesinde adı olmayan Subhi Ezel, İran'daki korku dolu günlerden kurtulmak ve geri planda kalmamak için gizlice kervana katılmaya karar verir. Yola çıkmak için Tahran'da babasından miras olarak kalan üç gayrimenkulü satmaya niyetlenen Subhi Ezel, bunlardan birine Şah tarafından el konulduğunu diğer ikisinin de kardeşi Mirza Hüseyin Ali tarafından satıldığını öğrenir. ${ }^{23}$

Elinde kalan tüm malları satar ve Ocak 1853'te yola çıkan kervana pamuk tüccarı bir Arap kimliğiyle gizlice dahil olur. Subhi Ezel, kafileden iki ay sonra Haziran 1853'te Bağdat'a ulaşır. Bağdat'a geldiğinde Arap mahallesinde bir ev tutar ve olup bitenleri uzaktan gözledikten sonra kendisi için sıkıntılı bir durum olmadığını sezince ortaya çıkar. Kısa sürede etrafına çok sayıda Babî toplamayı başarır. Böyle olunca da Bağdat'taki Babîler ikiye bölünürler. Onlardan bir kısmı "Beyan"a kati şekilde uyulması gerektiğini belirten katı tavırlı Subhi Ezel'e, diğer kısmı da dini emirlerin hayatı daha kolaylaştırması ve daha hoşgörülü olması gerektiğini söyleyen ılımlı Mirza Hüseyin Ali'ye tabii olurlar. ${ }^{24}$ Ilımlı söylemleriyle etrafındaki cemaat halkasını her geçen gün daha da genişleten Mirza Hüseyin Ali'nin artan otoritesi Subhi Ezel'i fazlasıyla rahatsız etmeye başlar. Fakat Kaçar ya da Osmanlı Devleti yetkilerinin gözüne de batmak istemediği için faaliyetlerini gizlice yürütmeye karar verir. Bu esnada kardeși Mirza Hüseyin Ali'den bir görüşme teklifi alır. Bu görüşmede Mirza Hüseyin Ali, Subhi Ezel'in sürgün edilenler arasında olmadığı için memleketi olan İran'a geri dönmesi ve

22 Karadeniz, İran'da Sömürgecilik Mücadelesi ve Kaçar Hanedanı, 179-180.

23 Browne, A Traveller's Narrative, 376.

${ }^{24}$ Browne, A Traveller's Narrative, 356. 
oradaki Babîlere sahip çıkmasını ister. Subhi Ezel ise orada can güvenliğinin olmadığını belirterek bu teklifi reddeder. ${ }^{25}$

Babîler arasındaki ağırlığını daha da arttırmak isteyen Subhi Ezel, Babîler arasında saygınlığı olan isimleri yanına çekmek için harekete geçer. İlk olarak kardeşinin de muhaliflerinden olan Seyyid Muhammed İsfehani ile anlaşır. Ardından Molla Muhammad Cafer Naraki, Molla Muhammad Taki, Hacı Seyyid Cevat Kerbalayi, Mirza Muhammed Hüseyin Mutavalli ve Molla Recep Ali Kahir'e de birer mektup yazarak onları da kendi yanında yer almaya davet eder. ${ }^{26}$

Bab'ın asıl halefinin kendisi olduğunu, Mirza Hüseyin Ali'nin Bab'ın getirdiği yasaları değiştirmeye çalışan bir yalancı olduğu haberini Bağdat'ta yayan Subhi Ezel, bu haberi Kerbela ve Yezd gibi şehirlerde yaşayan Babîlere de duyurur. Bu propaganda faaliyeti kısa süre içerisinde dönüt verir ve Subhi Ezel'in etrafındaki Babîlerin sayısı hızla artmaya başlar. ${ }^{27}$

Tüm bu yaşananlardan sonra Babî toplumunda büyük oranda güç kaybeden Mirza Hüseyin Ali, Nisan 1854'te Süleymaniye Dağlarında iki yıl inzivaya çekilir. Subhi Ezel kardeşine mektup yazıp aralarına tekrar dönmesini istese de bu talebine bir yanıt alamaz. Bu süre içerisinde Babî toplumundaki bölünme de artık iyiden iyiye belirgin hale gelmiştir. 1856 yılına gelindiğinde Subhi Ezel'in; Bab'ın eşlerinden biri olan Fatma Begüm Hanım ile evlendiği, bir ay sonra onu yeniden Seyyid Muhammed İsfehani ile nikahladığ ${ }_{1}{ }^{28}$ Bab'ın yeğeni Mirza Ali Ekber'i öldürtmek istediği, kendisine muhalefet eden Deyyan'ı hainlikle suçlayıp öldürtmeye çalıştığ ${ }^{29}$ gibi iddialar Babîler arasında hızla yayılır. Bu haberleri duyan Mirza Hüseyin Ali tekrar Bağdat'a döner. İki kardeşin yeniden bir araya gelmesiyle Babîler arasındaki anlaşmazlık artık çatışmaya dönüşür. Fakat Kaçar ülkesindeki Babîlerin yeniden tutuklanmaya başladığını duyan ve aynı durumun Bağdat'ta da yaşanabileceğini düşünen Subhi Ezel sükûnet çağrısında bulunur. Sonra da izini kaybettirmek için Bağdat'tan ayrılarak ilk önce Hacı Ali Lasfuruş takma ismiyle Basra'ya, ardından da Mirza Ali Kirmanşahi adıyla

25 Taherzadeh, Hz. Bahaullah'ın Zuhuru, 1/259-260.

26 Maceoin, "Divisions and Authority Claims in Babism (1850-1866)", 110; Browne, $A$ Traveller's Narrative, 356.

27 Șevki Efendi, Bahai Dininin I. Yüzyılı, 118-121,130.

28 Taherzadeh, Hz. Bahaullah'ın Zuhuru, 1/254.

29 Browne, A Traveller's Narrative, 357; Maceoin, "Divisions and Authority Claims in Babism (1850-1866)", 113; Azal, The Religion of The Bayan and The Claims of The Baha'is, 174,249 . 
Musul'a giderek oralarda ticaretle uğraşır. ${ }^{30}$

Bir süre sonra Babîlerin İstanbul'a gönderilecekleri haberini alan Subhi Ezel, bir taraftan İran ve Irak'tan ne kadar fazla uzaklaşırsa o kadar az tehlikede olacağı düşüncesiyle diğer taraftan da kardeşiyle yarım kalan liderlik mücadelesini orada devam ettirmenin daha kolay olacağ düşüncesiyle Osmanlıya gitmeye karar verir. Ancak bu sırada Mirza Hüseyin ise Bağdat'tan İstanbul'a doğru yola çıkar ve Bab'ın gelişini müjdelediği “Men Yuzhirullah"ın (Geleceği Haber Verilen Kişi) kendisi olduğunu yakın çevresine ilan eder. ${ }^{31}$ Artık bu tarihten sonra Mirza Hüseyin Ali ve taraftarlarının diğer Babîlerle olan yolları kesin çizgilerle olmasa bile ayrılır. Kardeşinin bu iddiasını işiten Subhi Ezel, böyle bir şeyin Bab'a ve öğretilerine ihanet olduğunu ilan eder. Onun bu çıkışı elini de güçlendirir ve etrafına toplanan Babîler sayısının artmasına vesile olur. ${ }^{32}$

\section{c. İstanbul Sürgünü}

Subhi Ezel, Mayıs 1863'te Bağdat'tan Osmanlı ülkesine yola çıkan kervana kimliğini gizleyerek ailesi ile birlikte katılır. Ağustos 1863'te İstanbul'a ulaşldıklarında Osmanlının başkentinde kendilerine yeni bir düzen kurmak isteyen Babîler henüz bu şehre alışmadan Kaçar yetkililerinin onların huzursuzluk çıkaracakları şeklinde Osmanlı idarecilerini uyardıklarını öğrenirler. Nitekim Osmanlı Sultanı Abdülaziz'de bu uyarıları dikkate alarak Ekim 1863 tarihli irade ile onları Edirne'ye sürer. ${ }^{33}$

\section{d. Edirne Sürgünü ve Babî Toplumunun Bölünmesi}

Subhi Ezel ve diğer Babîler, Aralık 1863'te İstanbul'dan yola çıkar ve on günlük bir yolculuktan sonra Edirne'ye ulaşırlar. Subhi Ezel burada ilk iş olarak bir taraftan Bab'ın vekilinin ve Babîlerin gerçek liderinin kendisi olduğu iddiasını tekrar dillendirmeye diğer taraftan da Babîler arasında taraftarı gittikçe artan kardeşi Mirza Hüseyin Ali'yi saf dışı bırakmak için planlar yapmaya başlar. ${ }^{34}$

İki kardeş arasındaki çekişme zaman içerisinde gittikçe şiddetlenir. Hatta birbirlerini zehirletmek ya da doğrudan öldürtmek için adam

\footnotetext{
30 Șevki Efendi, Bahai Dininin I. Yüzyıll, 170.

31 Taherzadeh, Hz. Bahaullah'ın Zuhuru, 1/264-266.

32 William Mc Cants - Kavian Milani, "The History and Provenance of an Early Manuscript of The Nuqtat al-kaf Dated 1268", Iranian Studies 37/3 (2004), 432.

33 Browne, A Traveller's Narrative, 359; Adip Taherzadeh, Hz. Bahaullah'in Zuhuru, çev. Süreyya Güler (İstanbul: Kazancı Matbaacılık, 1998), 2/71,169.

34 Taherzadeh, Hz. Bahaullah'ın Zuhuru, 2/154-155.
} 
tuttukları dahi iddia edilmektedir. ${ }^{35}$ Yaşanan bu olaylardan sonra kardeşine güveni kalmayan Subhi Ezel, onlarla olan tüm bağlarını koparır. ${ }^{36}$

Babîler arasındaki hizipleșmeye son vermek isteyen Mirza Hüseyin Ali, Mart 1866 'da aldığını iddia ettiği vahiy doğrultusunda kendisinin Tanrı'nın elçisi, Bab'ın gerçek vekili ve onun müjdelediği "Men Yuzhirullah" (Gelişi Haber Verilen Kişi) olduğunu resmen ilan eder. Subhi Ezel'den de kendisine biat etmesini ister. Fakat o, kardeşinin 1852'de Siyah Çal'da hapis olduğu süreçte de kendisine vahiy geldiği iddiasını hatırlatır ve asıl kendisinin vahiy aldığını ve Allah tarafından tüm insanların kendisine itaat etmelerinin emredildiğini beyan eder. Bu cevap karşısında kendisini çaresiz hisseden Mirza Hüseyin Ali yaklaşık iki ay bir süreyle inzivaya çekilir ve sonra da hiçbir açıllama yapmadan kendisinde bulunan Bab'ın mührünü37, el yazmalarını ve Osmanlı hükümeti tarafından Babîlere tahsis edilen ödeneğin yarısını Subhi Ezel'e gönderir. ${ }^{38}$

Yaşanan bu durum karşısında Mirza Hüseyin Ali taraftarları gibi Subhi Ezel ve onun taraftarları da büyük şaşkınlık yaşarlar. Bu gelişmenin ardından Babî toplumu içinde Subhi Ezel'in konumu tamamen değişir ve çevresindeki insan sayısı hızla artar. Gelişmelerden fazlasıyla hoşnut olan Subhi Ezel, İran'daki Babîlere mektup yazarak son durumu onlara da bildirir. Ardından bu işi tamamen bitirmek için Edirne Valisi'ne ve Kaçarların İstanbul Elçisi'ne, kendisinin özel elçiliğini yapan Seyyid Muhammed İsfehani'yi göndererek Mirza Hüseyin Ali'nin Osmanlı ve Kaçar Hükümdarlarına suikast düzenleteceğine dair duyumlar aldığı haberini iletir. Bu sayede hem onların güvenini kazanmayı hem de kardeşinin tehdidini tamamen ortadan kaldırmayı amaçlar. Öte yandan bunlardan haberdar olan Mirza Hüseyin Ali, sessizliğini bozarak yeniden ortaya çıkar ve ilk önce Subhi Ezel ile olan tüm bağlarını kopardığını ardından da Seyyid Muhammed İsfehani'yi cemaatten

35 Hasan M. Balyuzi, Bahaullah, King of Glory (Oxford: George Ronald Publishing, 2000), 225-226; Taherzadeh, Hz. Bahaullah'ın Zuhuru, 2/170-17.

36 Browne, A Traveller's Narrative, 359-360.

${ }^{37}$ Bab'a ait olduğu iddia edilen mühürde şu ifadeler bulunmaktadır: Innani ana hujjatu'llah wa nuruhu (Muhakkak ki ben Allah'ın hücceti ve nuruyum.) Shahida'llahu annahu la ilaha illa huwa'l-`Aziz al-Mahjub (Allah şahittir ki, O Allah kendisinden başka İlah olmayandır. O, azizdir gizlidir.)

Ya Ali Ya Muhammad (Ey Ali Ey Muhammed.) Ayrıntılı bilgi için bk. Edward G. Browne, "Personal Reminiscences of The Babi Insurrection at Zanjan in 1850", Journal of The Royal Asiatic Society 29/4 (October 1897), 764.

38 Şevki Efendi, Bahai Dininin I. Yüzyıll, 105,173; Azal, The Religion of The Bayan and The Claims of The Baha'is, 277-278. 
"Tard Ettiğini" 39 ilan eder. ${ }^{40}$ Böylece Babî toplumu içerisinde yıllardır süregelen fakat adı konmamış olan liderlik mücadelesi artık resmen aşikâr olur.

İki kardeş arasında yaşanan bu gerginlik Edirne'deki Babîlere de yansır ve onlar da birbirleriyle çatışmaya başlarlar. Bu durumdan rahatsız olan Mir Muhammed adındaki bir Babî, bu meselede kimin haklı kimin haksız olduğunun açıklığa kavuşması ve Babîlerin huzura ermesi için tarafları Eylül 1867'de bir heyetin önünde Selimiye Camii'nde tartışmaya davet eder. Tarafların ikisi de bu davete icap edeceklerini bildirdiler. Fakat kararlaştırılan gün Subhi Ezel, rahatsız olduğunu ileri sürerek toplantıya gelmez. Bunun üzerine Mirza Hüseyin Ali, kendisine Allah tarafından bildirildiğini iddia ettiği ikinci bir tartışma yeri ve zamanını Subhi Ezel'e tekrar iletir. Ayrıca Subhi Ezel'in şayet bu toplantıya da gelmeyecek olursa tüm iddialarından vazgeçtiğini belirten bir beyan yazmasını da ister. Fakat Subhi Ezel bu toplantıya gitmediği gibi herhangi bir yanıt da vermez. ${ }^{41}$

Mirza Hüseyin Ali'nin bu girişimleri karşısında sessiz kalmayı tercih eden Subhi Ezel, enerjisini Osmanlı bürokratları ile olan ilişkilerini kuvvetlendirmeye harcar. Bu işle de Seyyid Muhammed İsfehani'yi görevlendirir. Bu dönemde ilişki kurulan Osmanlı bürokratları arasında en dikkat çekici olanlardan biri Ağa Can'dır. İran asıllı olup Kaçar ordusunda görev yaparken Osmanlı ordusuna geçen ve orada üst düzey görevlerde bulunan Ağa Can, zamanla Subhi Ezel'in en yakın dostlarından biri olur. Hatta Subhi Ezel tarafından kendisine "Seyful Hak" (Allah'ın Kılıcı) lakabı verilir. Onun desteği sayesinde kendisini daha rahat hisseden Subhi Ezel'in planı, ajanlık yaptığı iddiasıyla Ağa Can'ın tutuklanmasıyla sona erer. Ağa Can'ın sorgusu sırasında verdiği bilgiler Subhi Ezel'in gücünün anlaşılması bakımından önemlidir. 0 , sorgusunda Seyyid Muhammed İsfehani aracılı̆̆ıyla haberleștiği Subhi Ezel'i şahsen tanımadığını fakat onun Osmanlı sevdalısı ve Kaçar sarayı da dahil olmak üzere İran'da çok sayıda taraftarı olan bir insan olduğunu ifade eder. ${ }^{42}$

Subhi Ezel cephesinde bunlar yaşanırken Mirza Hüseyin Ali de 21 Mart

39 Tard Etmek: Babîlik ve özellikle de Bahailikte büyük kusur işleyen bir kimsenin bu topluluklardan uzaklaştırılıp kovulması. Ayrıntılı bilgi için bk. Yasin İpek, "Alevilikteki Düşkünlük ile Bahailikteki Tard Anlayıșının Mukayesesi”, Route Educational and Social Science Journal 6/8 (September 2019), 174-176.

40 Taherzadeh, Hz. Bahaullah'in Zuhuru, 2/182-183,187.

41 Şevki Efendi, Bahai Dininin I. Yüzyıl, 175; Azal, The Religion of The Bayan and The Claims of The Baha'is, 277.

42 Browne, A Traveller's Narrative, 359; Taherzadeh, Hz. Bahaullah'ın Zuhuru, 2/345-346. 
1868 tarihinde "Emir"ini ilan eder ve bu tarihten sonra "Bahaullah" (Allah'ın Nuru) lakabıyla anılmaya başlanmıştır. Artık ona tabii olan Babîlere "Bahai", Subhi Ezel'e tabii olanlara "Ezeli", ikisine de tabii olmayanlara ise "Beyani Babî" denilir. ${ }^{43}$

Babîler arasında yaşanan çatışmaların gün geçtikçe artması, iki kardeşin mücadelede üstün gelmek için Osmanlı bürokratlarına yakınlaşmaya çalışmaları, özellikle Bahaullah'ın Ruslar ve bazı Batılılarla irtibatta olduğuna dair istihbari bilgilerin alınması Osmanlı idaresini fazlasıyla rahatsız eder. Ayrıca Subhi Ezel'in önderliğindeki Babîlerin dünyaya hâkim olacaklarını ifade eden Subhi Ezel'e ait sahte imzalı mektupların geceleri Edirne Valisi'nin evine bırakılması da ayrı bir rahatsızlı sebebi olur. ${ }^{44}$ Babîlerin sebep olduğu tüm bu sıkıntıları ortadan kaldırmak ve onları merkezden uzaklaştırmak için Osmanlı devleti radikal kararlar alınmasına hükmeder ${ }^{45}$ ve bu amaçla Nisan 1868'de eldeki istihbarat raporlarının toplanması ve değerlendirilmesi için dört kişiden oluşan bir heyet kurulur. Bu heyetin yaptığı araştırmalar neticesinde de Subhi Ezel ile Bahaullah'ın vahiy aldıklarını ve Kur'an- Kerim'e denk kitaplar yazdıklarını iddia eden, cahil insanların dini duygularını sömürüp kendilerini onlara peygamber gibi tanıtan sahtekâr insanlar olduğu sonucuna ulaşllır dolayısıyla bu sapkın insanların ve faaliyetlerinin derhal durdurularak onlara gerekli cezanın verilmesi gerektiği vurgulanır. ${ }^{46}$

Hazırlanan raporda bahsedilen hususları değerlendiren Osmanlı Sultanı Abdülaziz, 11 Temmuz 1868 tarihli iradesi ile olayların temel sorumluları oldukları anlaşılan Subhi Ezel ve Bahaullah'ın cezalandırılmasına hükmeder. Verilen karar sonrasında asıl iki suçludan biri olan Subhi Ezel'in ailesi ve dört Bahai (Miskin Kalem Mirza Hüseyin, Mirza Ali Seyyah, Muhammed Bakır İsfehani ile Abdul Gaffar) Kıbrıs Mağusa'ya; diğer suçlu Bahaullah'ın ise ailesi ve Seyyid Muhammed İsfahani, Ağa Can Bey, Mirza Rıza Kuli ile Mirza Nasrullah gibi dört Ezeliyle ${ }^{47}$ Filistin Akka'ya nefyi ebed (ebedi sürgün) cezası ile kalebend (kale hapsi) olarak gönderilmelerine, ikisinin de ağır ceza mahkûmu oldukları için gittikleri yerlerde kimseyle görüştürülmemelerine, taraftarlarının ise dağıtılarak

43 İpek, Yeni Bir Dini Hareket Olarak Bahailik ve Türkiye'de Bahailer, 148.

${ }^{44}$ Ruhi, "A Brief Biography of His Holiness Subh-i Azal".

45 Browne, A Traveller's Narrative, 360.

46 Süleyman Özkaya, Osmanlı Arşiv Belgeleri Işığında Bahailik Hareketi (İzmir: Akademi Kitabevi, 2000), 77,79.

[56 $\quad 47$ Bu dört Ezeliden Mirza Nasrullah'ın yolculuğa başlamadan önce, diğer üçünün ise Akka'ya vardıktan kısa bir süre sonra Bahaullah tarafından öldürtüldüğü iddia edilmektedir. Ayrıntılı bilgi için bk. Browne, A Traveller's Narrative, 361. 
karışık şekilde gönderilmelerine karar verilmiştir.48

\section{e. Mağusa Sürgünü ve Subhi Ezel'in Ölümü}

Subhi Ezel'in de içinde bulunduğu sürgün kafilesinde kaç kişi olduğuna dair farklı rivayetler mevcuttur. Bazı kaynaklarda on sekizi Ezeli, dördü de Bahai toplam yirmi iki kişiden bahsedilmiş ve Ezelilerden on birinin de adaya geldikten sonra Bahai oldukları ifade edilmiștir. ${ }^{49}$ Fakat Kıbrıs İngiliz Komiserliğinin hazırladığı raporlara göreyse sürgünle gelenlerin sayısının yirmi iki değil, ikisi hizmetçi olmak üzere toplam on altı kişi olduğu ifade edilmiştir. Hatta onların kim olduklarına ve inançlarına dair belge dahi düzenlenmiştir. Bu belgeye göre sürgün fermanıyla Kıbrıs'a gönderilen kimseler: Subhi Ezel ve ailesinden (Eşleri Fatma ve Rukiyye; oğulları Abdulali, Ahmet, Rıdvan Ali ve kızları Behjet Rafet, Fatma, Safiye, Talat) toplam on kişi; Bahailerden Şeyh Ali Seyyah, Miskin Kalem, Abdul Gaffar ve Muhammed Bakır toplam dört kişi ve iki de hizmetçi olmak üzere toplam on altı kişiden oluşan gruptur. ${ }^{50}$

Kıbrıs'ta yaşamaya başladığı ilk zamanlarda büyük maddi sıkıntılar çeken Subhi Ezel, bir dönem Kaçar ve Osmanlı ülkelerindeki Ezelilerden gelen yardımlarla hayatını idame ettirir. Artık Babîlik ya da Ezelilik hakkında herhangi bir faaliyette bulunmayan Subhi Ezel, bu dönemde İran Zencan'dan Kıbrıs'a gelen üç Babînin kendisine tabii olma isteklerini dahi reddeder. ${ }^{51}$

Kıbrıs'taki yerel halka geçmişinden hiç bahsetmeyen Subhi Ezel, burada münzevi bir hayat yaşamayı seçer. Eşlerinden ve çocuklarından ayrı şekilde küçük bir evde yalnız başına kalan Subhi Ezel, ancak on on beş günde bir ihtiyaçlarını karşılamak ve ailesini görmek için evine gider. Bu uhrevi görüntüsü ve yaşam tarzı onu zaman içerisinde Kıbrıs'ın saygın dini simalarından biri haline getirir. Kıbrıs halkının Şia inancına mensup bir molla olarak bildiği Subhi Ezel'in gerçekte kim olduğunu ailesinden başka sadece adada kendisi gibi sürgünde olan Namık Kemal ${ }^{52}$ gibi entelektüel insanlar ve

48 Ruhi, "A Brief Biography of His Holiness Subh-i Azal”, Taherzadeh, Hz. Bahaullah'in Zuhuru, 2/428-429.

49 Fığlalı, Babilik ve Bahailik, 55.

${ }^{50}$ Browne, A Traveller's Narrative, 385-389; Ruhi, “A Brief Biography of His Holiness Subhi Azal".

51 Browne, "Personal Reminiscences of The Babi Insurrection at Zanjan in 1850", 762.

52 Dönemin ünlü Osmanlı yazar ve düșünürlerinden biri olan Namık Kemal, Osmanlı yöneticilerine yazmış olduğu mektuplarda Babîler diye bahsettiği Ezelileri; dünyanın hiçbir yerinde istenmeyen ve katillerden bile daha fena insanlar diye nitelemiştir. Ayrıntılı bilgi için bk. Bedri Aydoğan, "Namık Kemal'in Magosa Sürgünlüğü", Çukurova Üniversitesi Sosyal Bilimler Enstitüsü Dergisi 12/12 (Eylül 2003), 19. 
Yasin IPEK

1878'den sonra da ada yönetimini ele alan İngiliz yetkililer biliyorlardı. 53

Kıbrıs'ın 1878 yılında İngilizlerin kontrolüne girmesi Mağusa Kalesi'ndeki sürgün hayatı devam eden Subhi Ezel için de bir dönüm noktası olur ve anlatılanlara göre İngiliz hükümeti Kıbrıs Komiserliğinden kalede kaç hükümlü olduğuna ve neyle suçlandıklarına dair bir rapor ister. Bölge komiserliği de kalede biri Yunanistanlı hırsız, biri Mustafa isminde bir Bosnalı, biri İslam'a hakaret eden Yusuf adlı bir Türk ve yeni bir din icat ettikleri için İran'dan Osmanlıya kaçıp orada da söylemlerine devam eden Subhi Ezel ve Miskin Kalem isminde iki İranlının olduğunu rapor eder. Rapor sonrasında durumları İngiliz makamları tarafından görüşülen mahkumlardan Subhi Ezel'in Mağusa'daki sürgün hayatı 1881'de sona erdiril ve istemesi halinde adadan ayrlabileceği bildirilir. 0 ise bu teklifi kabul etmez. Bu sırada Subhi Ezel, İngiliz vatandaşlığına geçmeyi istese de bu isteği kabul edilmez. Fakat ihtiyaçlarını giderebilmesi için İngiliz hükümeti tarafından ailesiyle birlikte kendisine ve sürgünle gelen diğerlerine emeklilik hakkı tanınır ve maaşa bağlanırlar. ${ }^{54}$

Subhi Ezel, Temmuz 1911'de hastalanır. Rahatsızlığı günden güne artar ve hayatını tamamen kısıtlar. Eylül ayına gelindiğinde artık iyice güçsüzleşir. Bu rahatsızlıktan sonra ağırlaşan Subhi Ezel Mirza Yahya Nuri, 29 Nisan 1912 Pazartesi sabahı seksen yaşındayken Mağusa'da vefat eder. Subhi Ezel öldügünde çevresinde neredeyse yok denecek kadar az sayıda Ezeli kalmıştır. Hatta oğullarından Ahmet'in Hayfa'ya yerleşip Bahai olduğu, diğer oğlu Rıdvan Ali'nin babası öldüğünde Ortodoks Hıristiyan olduğu ve ismini de Costi Persianis şeklinde değiștirdiği dahi iddialar arasındadır. ${ }^{55}$

Subhi Ezel'in cenazesi, ailesi, yöre halkı ve Mağusa'daki Müslüman din adamları tarafından, vasiyeti üzerine Barutcuzade Hacı Hafız Efendi'nin evinin yakınına defnedilir. Ölümünden sonra cenazesi ile ilgili çeşitli söylentiler de yazılır. Örneğin Bahai kaynaklarında cenazesini kaldıracak kimse olmadığı iddia edilirken diğer kaynaklarda cenazeye Kıbrıs'ın her tarafından devlet yetkilileri ve halktan çok sayıda insanın katıldığı hatta evinden defnedileceği yere kadar büyük bir hürmetle omuzlarda taşındığı ve İslami geleneklere göre defnedildiği ifade edilmektedir. ${ }^{56}$

\footnotetext{
53 Mete Hatay, "Kıbrıs'ta Yaşayan Son Ezeliler”, Nehaberkibris (Erişim 1 Nisan 2021).

${ }^{54}$ Browne, A Traveller's Narrative, 380; Momen, "Mirza Yahya".

55 Hatay, "Kıbrıs'ta Yașayan Son Ezeliler"; Azal, The Religion of The Bayan and The Claims of The Baha'is, 169-170.

56 Browne, Materials for the Study of the Babi Religion, 312; Harry Charles Lukach, The Fringe of the East; A Journey Through Past and Present Provinces of Turkey, (Warszawy: Wentworth Press, 2019), 264-266.
} 
Subhi Ezel'in torunlarından bazıları günümüzde de Kıbrıs'ta yaşamaktadırlar. Fakat bunlar, Ezeli soyundan geldiklerini kabul etmekle birlikte Ezeli inancına mensup olmadıklarını ifade etmektedirler. Onlara göre Ezelilik artık bir din değil kültürel mirastır. ${ }^{57}$

Subhi Ezel'in Gazimağusa'da Larnaka Yolu üzerindeki türbesine başta İran olmak üzere diğer ülkelerdeki Babîlerden halen ziyarete gelenler mevcuttur. Günümüzde bu türbenin bakımını ve gelen ziyaretçilerle ilgilenme görevini Subhi Ezel'in ikinci kuşak torunları üstlenmiştir. 58

\section{Ailesi ve Eserleri}

Mirza Yahya daha çocuk denecek yaştayken ilk evliliğini gerçekleştirmiş ve ilerleyen yıllarda birkaç evlilik daha yapmıştır. Kaç defa evlendiği ve kaç çocuğu olduğuna dair kaynaklarda net bir bilgi olmamakla birlikte özellikle onun torunlarıyla yapılan görüşmelerden anlaşıldığına göre Subhi Ezel, en az beş kez evlenmiş ve bu evliklerden en az on altı çocuk sahibi olmuştur.

\section{a. Eşleri ve Çocukları}

Mirza Yahya'nın sayıları kesin bilinmemekle birlikte isimlerini tespit edebildiğimiz beş eşi şu kimselerdir: İran'dayken evlenip beraberinde Bağdat'a götürdüğü Nergis ve Meryem Hanım, yine İran'dayken evlendiği ve Kıbrıs'a kadar birlikte gittiği Bab'ın ikinci eşi olan Fatma Begüm Hanım ve (onun kardeși olduğu iddia edilen) Rukiyye Hanım ile Mülki Cihan Hanım. ${ }^{59}$

Mirza Yahya'nın tespit edebildiğimiz beş evliliğinden dokuzu erkek, yedisi de kız olmak üzere isimlerine ulaşabildiğimiz en az on altı çocuğu vardır. Mirza Yahya'nın oğullarının isimleri; Abdulali Ezel, Abdulvahid Ezel (Abdulcelil/ Abdurraşid), Ahmet Behaj, Fuad Ezel, Hadi Ezel, Muhammed Hadi Abga, Nurullah Tamarah, Rıdvan Ali Ezel ve Takiyuddin (Ziyauddin) Ezel'dir. Kızlarının isimleri ise; Fatma, Hibatullah (Jazbatullah), Meryem Ezel (Qanita), Müshiyatullah, Rafet Ezel (Behcetul Kuds), Safiye Ezel ve Talat Ezel'dir. ${ }^{60} \mathrm{Bu}$ çocuklardan bir kısmı Kıbrıs'ta babasıyla beraber yaşamış diğerleri ise zaman içerisinde Türkiye, İran, Almanya ve Fransa gibi ülkelere

\footnotetext{
57 Hatay, "Kıbrıs'ta Yaşayan Son Ezeliler".

58 Mete Hatay, "Suphi Ezel'in Cenaze Töreni ve Sonrası", Havadiskibris (Erişim 1 Nisan 2021).

${ }^{59}$ Browne, Materials for the Study of the Babi Religion, 384; Azal, The Religion of The Bayan and The Claims of The Baha'is, 169.

60 Azal, The Religion of The Bayan and The Claims of The Baha'is, 168-169; Browne, Materials for the Study of the Babi Religion, 385; Browne, "Personal Reminiscences of The Babi Insurrection at Zanjan in 1850", 767; Ruhi, "A Brief Biography of His Holiness Subhi Azal".
} 
yerleşmişlerdir. ${ }^{61}$

\section{b. Eserleri}

Mirza Yahya tarafından "Kitabı Nur" adlı kitabı başta olmak üzere kaleme alınmış çok sayıda eser vardır. Daha çok Babîliğin esaslarının işlendiği bu eserler arasında birçok şiir de mevcuttur. Bu eserlerden bir kısmı Subhi Ezel'in düşmanları tarafından yok edilmiş bir kısmı da zaman içerisinde ya tahrif olmuş ya da kaybolmuştur. Kitap ve kitapçık şeklindeki bu eserlerden geride kalanların sayısının yüz yirmi civarında olduğu varsayılmaktadır. Bu eserlerin çoğu Amerika Birleşik Devletleri'ndeki Princeton Üniversitesinde (New Jersey), Fransa'daki Ulusal Kütüphanede (Paris), İngiltere'deki İngiliz Müzesi Şark Kütüphanesi Koleksiyonu'nda (Londra) ve Cambridge Üniversitesi Browne Koleksiyonu'nda (Cambridge) bulunmaktadır. ${ }^{62}$

\section{Bab'ın Vekilliği Meselesi}

Mirza Ali Muhammed'in (Bab) hapiste olması ve geride kalan Babîlerin başına buyruk hareket etmeleri hem kendilerine hem de bu inanca mensup olan diğer insanlara zarar vermeye başlayınca Babîler arasında yeni bir lider seçme gereği duyulmuştur. Bu süreçte Babî toplumu içerisinde saygın bir konuma sahip olan iki kardeşin yani Mirza Yahya (Subhi Ezel) ve Mirza Hüseyin Ali'nin (Bahaullah) isimleri ön plana çıkmıştır. Başlangıçta her ikisi de liderliğe çok hevesli gibi görünmeyen bu iki kardeşten her biri, etrafına toplanan insanların sayısı arttıkça ve onların da teşvik etmeleriyle birlikte Bab'ın asıl vekilinin kendisi olduğu iddiasını yüksek sesle dile getirmeye başlamışlardır. Bab, "Beyan" kitabında ${ }^{63}$ ve idam edilmeden önce el yazısıyla yazıp mühürlediği vasiyetinde kendisinden iki bin yll sonra ortaya çıkacak olan "Müsteğas"a (Yardıma Gelecek Kimse) kadar herhangi bir zuhur olmayacağını ifade etmiş ve halefi olarak Mirza Yahya'yı tayin ettiğini açıklamıştır. ${ }^{64}$ Bab tarafından, yazmış olduğu eserleri en iyi bilenlerden biri olarak nitelenen ve bu özelliği sebebiyle Bab'ın nazarında ve diğer Babîler arasında özel bir konuma sahip olan Mirza Yahya, ${ }^{65}$ Bab’ın bu açık ifadelerini

${ }^{61}$ Hatay, "Kıbrıs'ta Yaşayan Son Ezeliler".

62 Momen, "Mirza Yahya"; Edgar Blochet, "A Preliminary List of The MSS of The Works of Subh-i Azal Held at The Bibliotheque Nationale of Paris", trans. Wahid Azal, Catalogue Des Manuscrits Persans De La Bibliotheque Nationale (Berlin: 2015), 4/3-15.

63 Browne, Materials for the Study of the Babi Religion, 312.

64 Manuchehri, "The Primal Point's Will and Testament". 
de kendi liderliğinin delili olarak kabul etmiştir. Bu esnada kendisi için en büyük rakip olarak gördüğü kardeși Mirza Hüseyin Ali'nin de bir sahtekâr olduğu haberini etrafa yaymıştır. İki kardeş arasında baş gösteren bu çekişme zamanla Babî toplumunda da ayrllıklara ve bölünmelere sebep olmuştur.

Mirza Yahya'nın Bab'ın vekili olduğuna dair diğer bir iddiaya göreyse Mirza Yahya, yaygın kanaatin aksine "Hurufu Hay"ın (Diri Harfler) dördüncüsüdür. ${ }^{66}$ Kendisinden önceki Mirza Ali Muhammed (Bab) (ö. 1850), Molla Muhammed Ali (Kuddüs) (ö. 1849), Molla Hüseyin Busriye (Babül Bab) (ö. 1849) öldükleri için Bab'ın vekaleti olağan olarak Mirza Yahya'nın hakkıdır. ${ }^{67}$

Sonuçta iki kardeş de vekilliklerini ilan etmiş ve Babî toplumunun parçalanmasına sebep olmuşlardır. Fakat Bab’ın idam edilmesinin ardından; halef ilan edilen Mirza Yahya'nın kendi başına da bir şeyler gelebileceği endișesiyle uzun süre ortadan kaybolması; Mirza Hüseyin Ali'nin de Kerbela'yı ziyaretinden dolayı dokuz ay İran'dan ayrılması, hemen ardından Siyah Çal'da hapsedilmesi, sonra da Bağdat'a sürgün edilmesi ve Süleymaniye'de inzivaya çekilmesi sebebiyle ortada olmaması Babîlerin yeniden lidersiz kalmalarına sebep olmuştur. 68

Bab'ın halefinin kim olduğu sorusu o günlerde Babîler için büyük tartışmalara ve ayrllıklara sebep olduğu gibi günümüzde de devam etmektedir. İki tarafta birbirini sahtekârlıkla suçlamakta ve karşı grubun inancını dahi sorgulamaktadır. Babîlerin bir kısmı Bab'ın açık şekilde kendisine vekil tayin ettiği kişinin Mirza Yahya olduğunu iddia etmiş ve ona tabii olmuşlardır. Bunlar günümüzde "Ezeliler" adı altında varlıklarını sürdürmektedirler. Günümüzde çoğunluğu İran'da yaşayan ve sayıları birkaç binle ifade edilen Ezeliler, kendilerini Babîliğin devamı olarak görmektedirler. ${ }^{69}$ Mirza Hüseyin Ali'nin taraftarları ise Bab'ın Mirza Yahya'yı vekil tayin etmesi olayına iki farklı yorum getirmişlerdir. Birincisinde bu tayin olayı kabul edilmekle birlikte işin hakikatinin şu şekilde olduğu iddia edilmektedir: Bab, Mirza Yahya'yı üstün vasıflara sahip olduğu için değil, Mirza Hüseyin Ali'nin başına gelebilecek tehdit ve saldırıları engellemek için

\footnotetext{
66 Hurufu Hay (Diri Harfler): Bab'ın en yakınında olan ve onun öğretilerini yaymaya çalışan, Bab Mirza Ali Muhammed dahil on dokuz kişilik Babî gruptur. Ayrıntılı bilgi için bk. İpek, Yeni Bir Dini Hareket Olarak Bahailik ve Türkiye'de Bahailer, 87-94.

${ }^{67}$ Browne, A Traveller's Narrative, XVI; Carus, "A New Religion. Babism”, 359.

68 Şevki Efendi, Bahai Dininin I. Yüzyılı, 132.

69 David V. Barret, The New Believers (London: Cassell \& Co, 2001), 246; Azal, The Religion of The Bayan and The Claims of The Baha'is, 174.
} 
kendisine vekil tayin etmiştir. Böylece asıl vekilini korumuştur. Hatta Abdulbaha referanslı Bahai kaynaklarına göre vekil olarak Mirza Yahya'yı seçmesini Bab'a bizzat Mirza Hüseyin Ali teklif etmiştir. ${ }^{70}$ İkincisine göreyse tayin olayı hiçbir zaman olmamıştır. İddia edilen belge Mirza Yahya tarafından düzenlenmiş sahte bir evraktır. İşin aslı şu şekildedir: Babîler tarafından lider olarak kabul edilen Mirza Hüseyin Ali, Mirza Yahya'yı Bab'ın yazılarını düzenleme ve kopyalamakla görevlendirmiștir. Uzun süre bu görevi yapan Mirza Yahya, Bab'ın el yazısını taklit etmeyi çok iyi öğrenmiş ve onun yazılarını kendi lehine olacak şekilde baştan düzenleyerek kendisini Bab tarafından vekil olarak tayin edilmiş gibi gösteren sahte belgeyi hazırlamıştır. ${ }^{71}$ Vekilliğin Mirza Hüseyin Ali'nin hakkı olduğunu düşünen bu grupsa zaman içerisinde "Bahailik" adı verilen dini harekete (Kendileri din olduklarını iddia etmektedirler.) dönüşmüştür. Günümüzde Dünya'nın birçok ülkesinde yaşayan ve sayıları beş milyon civarında olan Bahailer, Babî kökenlerini kabul etmekle birlikte müstakil bir inanca dönüştüklerini iddia etmektedirler. ${ }^{72}$

\section{B. Ezelilik ve Ezeliler}

\section{Subhi Ezel'den Günümüze Ezeliler}

1844 yllında Mirza Ali Muhammed'in "Hakikate Açılan Kapı" (Bab) olduğunu ve yeni bir şeriat getirdiğini ilan etmesinden sonra ona tabii olanlara Babî denmiştir. Onun 1845'te Şiraz'da ardından da 1847'den itibaren Makü ve Çehrik Kaleleri ile Tebriz'deki hapisliği süresince Babîler, onun ziyaretçileri ya da gönderdiği mektuplar vasıtasıyla bir iletişim ve yönetim sorunu yaşamamışlardı. Fakat 1850 'de idam edilmesinin ardından Bab'ın vekilinin ve Babî toplumunun liderinin kim olacağı sorunu ortaya çıkmıştı. Başlangıçta Babîler, Bab’ın bizzat "Subhi Ezel” diye işaret ettiği kişi olan Mirza Yahya'nın etrafında toplanılmışlardı. Fakat Mirza Yahya'nın kardeşi olan Mirza Hüseyin Ali'nin de liderlik ve vekillik konusunda ortaya çıkmasıyla birlikte Babîler arasındaki asıl çatışma ve ayrışmalar da başlamıştı. Bab’ın asıl vekilinin kim olduğu konusundaki çekişme zamanla daha da hararetlenmiş ve birbirlerini sahtekarlıkla suçlamaya, öldürtmeye çalışmaya, yerel ve ulusal yöneticilere şikâyet etmeye kadar varmıştır. Artık iki kardeşin mücadelesi olmaktan çıkan bu çekişme tüm Babî toplumunu da etkilemiş ve ortaya üç farklı Babî temelli oluşum çıkmıștır. Bunlar "Bahailer",

\footnotetext{
${ }^{70}$ Abdubaha, A Traveler's Narrative Written to Illustrate the Episode of The Bab, trans. Edward G. Browne (Wilmette: Bahai Publishing Trust, 1980), 37.

71 Taherzadeh, Hz. Bahaullah'ın Zuhuru, 1/. 260-261.

72 İpek, Yeni Bir Dini Hareket Olarak Bahailik ve Türkiye'de Bahailer, 409.
} 
"Ezeliler" ve "Beyani Babîler"dir. İran'da dahil olmak üzere Dünya genelindeki Babîlerin büyük çoğunluğu Bahailiği seçmişlerdir. Ezeliler ise kendilerini Bab'ın asıl vekili olan Subhi Ezel vasıtasıyla Babîlik hareketini orijinal haliyle devam ettiren Babî topluluk olarak ifade etmektedirler. Günümüzde birkaç binlerle ifade edilen ve büyük çoğunluğu İran'da ikamet eden Ezelilerin belli bir liderleri bulunmamaktadır. ${ }^{73}$ Babîlerin geri kalanları ise bu iki kardeşten hiçbirine tabii olmadıkları gibi bunları kendi şahsi menfaatleri için Bab'ı kullanan insanlar olarak gördüklerini ifade etmektedirler. Bir idareciye ihtiyaçları olmadığını ve Bab'ın "Beyan" kitabının kendileri için yeterli olduğunu savunan bu grubun üyelerine "Beyani Babîler" denmiştir. Sayıları çok az olan Beyanilerin tamamına yakını İran'da ikamet etmektedirler. ${ }^{74}$

Subhi Ezel'in hayatta olduğu dönemde dahi sayıları çok fazla olmayan Ezeliler, özellikle Kıbrıs sürgününden sonra hızla kan kaybetmişler ve nerdeyse sadece Ezel sülalesiyle sınırlı kalmışlardır. Bir nevi aşiret yapısına da bürünen Ezeliler, Subhi Ezel'in Nisan 1912'de vefat etmesinden sonra büyük çaplı olmasa da bir iktidar sorunu yaşamışlardır. Bunun en büyük sebebi de Subhi Ezel'in vekil olarak yerine kimi bıraktığı ya da ölümünden sonra yerine kimin geçeceği sorusuna net bir cevabın olmayışıdır. Bunla ilgili farkı bilgiler mevcuttur. Bunlardan ilki, Subhi Ezel ölümünden sonra halefi olarak yerine oğlu Ahmet Bahhac'ın geçmesini istemiştir fakat aile içerisinde çıkan bir anlaşmazlıktan sonra bu kararını değiștirerek diğer oğlu Mirza Hadi Devletabadi'yi kendisine vekil tayin etmiştir. Mirza Hadi'nin 1908'de ölmesi üzerine bu yetkiyi onun oğlu olan ve Tahran'da bürokratlık yapan torunu Mirza Yahya Devletabadi'ye devretmiștir. ${ }^{75}$

Konuyla ilgili Bahailer tarafından dile getirilen bir iddiaya göreyse Subhi Ezel, yerine geçmesini istediği Mirza Hadi Devletabadi'nin Bab ve kendi öğretilerine olan inancında bir sıkıntı olduğunu sezmiştir. Hatta en büyük rakibi olan Bahaullah bile Mirza Hadi Devletabadi'nin inanç noktasında sıkıntıda olduğu belirttiği birçok levihin de kendi zuhurunu kabul etmesi için ona açıkça çağrıda bulunulmuştur. Bu davetine olumlu yanıt alamayan Bahaullah, onun sakalı ve cübbesiyle dindar görünümlü, cahil

73 Cole, "The Azali- Bahai Crisis of September 1867", 227; Denis Maceoin, "Azali Babism", Encyclopaedia Iranica (New York: Columbia University Publishing, 1989), 3/181; Barret, The New Believers, 246; Azal, The Religion of The Bayan and The Claims of The Baha'is, 174.

${ }^{74}$ Edward G. Browne, "Babism", Religious Systems of The World: A Contribution to the Study of Comparative Religion (London: Swann Sonnenschein 1890), 351.

75 Browne, Materials for the Study of the Babi Religion, 312; Maceoin, "Azali Babism", 3/181; Momen, "Mirza Yahya". 
insanları aldatan sahtekâr biri olduğunu ifade etmiştir. ${ }^{76}$ Mirza Hadi Devletabadi, babasının halefi olamayacağını anlayınca da Babîlik adına yaptığı tüm faaliyetleri bırakarak bir kenara çekilmiştir. Bahaullah'ın ölümünün ardından birkaç akrabası ile birlikte Abdulbaha'yı ziyarete gidip bağışlanma talep etmiş ve affedilmesinden sonra ölene kadar Bahai inancına

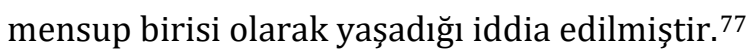

Diğer bir görüşe göreyse Subhi Ezel oğullarını karşısına alıp içlerinden hangisinin yaşam tarzı bakımından kendisine çok benziyorsa onu kendi yerine vekil tayin edeceğini söylemişse de oğullarından hiçbiri bunu istememiştir. Bunun üzerine o da makamını torunu Mirza Yahya Devletabadi'ye bırakmıştır. ${ }^{78}$

Bu konudaki son iddiaya göreyse Subhi Ezel kendisinden sonra yerine geçmesi için kimseyi işaret etmemiş ya da ismini vermemiştir. ${ }^{79}$

Netice itibarıyla Subhi Ezel'den sonra Ezelilerin başına kimin geçtiği konusunda bir fikir birliği ya da kesin bir bilgi olmamakla birlikte torunu Mirza Yahya Devletabadi'nin bu vazifeyi üstlenmiş olması ihtimali diğer iddialara göre daha kuvvetlidir.

Ezelilerin başlangıçta da günümüzde de nüfuslarının en fazla olduğu coğrafya İran'dır. Subhi Ezel İran'dan ayrıldıktan sonra burada kalan Babîler, bazı kimselerin önderliğinde varlıklarını devam ettirmişlerdir. Bu kişiler ve etki alanları şu şekildedir: Kazvin ve çevresinde Muhammed Hasan Fata ve Molla Hadi Kazvini, Kaşan ile Nerag ve çevresinde Molla Cafer Naragi, İsfahan çevresinde Bab'ın kayınbiraderi olan Molla Recep Ali Kahir ile kardeşi Molla Ali Muhammed Siraj ile Mirza Hadi Devletabadi, Kirman ve çevresinde Molla Muhammed Cafer Kirmani, Nur ve çevresinde Subhi Ezel'in üvey kız kardeşi ile akrabaları Babîleri ve Ezelileri etraflarına toplamışlardır. Fakat Kaçar ülkesinde başlayıp Osmanlı topraklarında devam Subhi Ezel ile Bahaullah arasındaki çekişme geride kalan Babîler için de sıkıntıya sebep olmuştur. İran'daki Babîler arasında da ayrılıklar ortaya çıkmaya başlamıştır. Bu sorunu çözmek için aralarından seçtikleri temsilcileri Mağusa ve Akka'ya göndermişlerse de bu kişiler geri döndüklerinde Babîliği terk ederek ya Bahai ya da Müslüman olmuşlardır. ${ }^{80}$

76 Bahaullah, Hz. Bahaullah'ın Levihleri, çev. Mecdi İnan (İstanbul: Menteş Matbaası, 1994), 49.

77 Şevki Efendi, Bahai Dininin I. Yüzyılı, 243-244.

78 Browne, Materials for the Study of the Babi Religion, 313.

79 William M. Miller, The Baha'i Faith: Its History and Teachings (Pasadena: William Carey Publishing, 1974), 107.

${ }^{80}$ Momen, "Mirza Yahya". 
Geri kalan Ezeliler ise Kaçar halkının ve yönetiminin Babiliğe karşı besledikleri menfi hislerinden dolayı kimliklerini gizlemişlerdir (Takiyye yapmışlardır.). Bu sebeple dindar Şii kimliğine bürünen Ezeliler zamanla Kaçar Devleti'nde etkili olmayı başarmışlardır. Hatta Subhi Ezel'in damatları olan Şeyh Ahmet Ruhi ve Mirza Hüseyin Kirmani gibi Ezeli olduklarını gizleyen bazı isimler İran siyasetinde önemli görevler dahi üstlenmişlerdir. Fakat bu iki kişi, 1895'te Nasıruddin Şah'a düzenlenen suikastın azmettiricilerinden oldukları gerekçesiyle idam edilmişlerdir. Daha sonraki süreçte Mirza Nasrullah Malikul Mütekallimin ve Seyyid Cemaleddin İsfahani gibi Ezeli olduklarını gizleyen din adamları 1906'da “Meclisi Şurayı Milli”nin açılışı ve "Kanuni Esasi” nin hazırlanması gibi Kaçar Devleti'ndeki meşrutiyet hareketlerinde aktif rol oynamışlardır. ${ }^{81}$

Subhi Ezel'in Kıbrıs'a sürgünü sonrası İran'da kalan Ezelilerin sayısı zamanla azalmış ve neredeyse bitmeye yaklaşmıștır. Subhi Ezel'in on altı civarında çocuğu ve bunların çocuklarının çoğu da diğer Ezeliler gibi ya Bahai ya Müslüman ya da Hıristiyan olmuşlardır. ${ }^{82}$

\section{Ezelilerde İtikadi, Ameli ve Ahlaki Esaslardan Bazıları}

Ezeliler kendilerini köken olarak Babîliğe bağlamakla birlikte, Bab'ın vekilliği konusunda Subhi Ezel'e tabii oldukları ve onun çizgisinden gittikleri için yine kendileri gibi Babî kökene dayanan Bahailerden ayrışmaktadırlar. Çıkış noktaları aynı olan bu Babî hareketlerinin aralarındaki en bariz iki farkı şu şekilde özetleyebiliriz: Birincisi Bab'ın vekilliği konusunda Ezeliler, Subhi Ezel'in Bab tarafından açıkça vasi tayin edildiğini ve Bahaullah'ın bir sahtekâr olduğunu iddia ederlerken Bahailer, Bab'ın asıl halefinin Bahaullah olduğunu ve Subhi Ezel'in kasıtlı olarak bir nevi piyon gibi öne çıkarıldığını iddia ederler.

İkincisi ise Ezeliler kendilerini Babîliğin devamı olarak görüp onun esaslarını kabul etmişlerdir. Bu sebeple itikadi, ameli ve ahlaki esaslarını "Beyan"ın hükümlerine göre belirlemişlerdir. Bahailer ise kendilerini müstakil bir din olarak lanse etmişlerdir. "Beyan"ı kutsal olarak kabul ettiklerini ifade etmekle birlikte onun birçok hükmünü ya yeniden düzenlemişler ya da tamamen kaldırmışlardır. Bu sebeple itikadi, ameli ve ahlaki esaslarını “Kitab’ul Akdes” in (Akdes Kitabı) hükümlerine göre yeniden

81 Yasin İpek, İran'da Kaçar Türk Hanedanlığı- Babilik ve Bahailik (İstanbul: Ekim Yayınları, 2010), 125; Maceoin, "Azali Babism", 3/180; Peter Smith, A Concise Encyclopedia of the Baha'i Faith (Oxford: Oneworld Publications, 2000), 54; Momen, "Mirza Yahya".

82 Momen, "Mirza Yahya". 
belirlemişlerdir.

Ezeliliğe dair tüm itikadi, ameli ve ahlaki esasları burada vermemiz mümkün olmadığı için biz de dikkat çekici bulduğumuz belli başlı esasları vereceğiz.

\section{a. İtikadi Esaslardan Bazıları}

Ezelilerde Allah'ın varlığı ve birliği, kutsal kitap, peygamber ve ahiret inancı gibi temel inanç esasları hakkında "Beyan" merkezli bir inanç hakimdir. Ezelilere göre bir kimsenin imanlı olup olmadığının temel belirleyicisi “La İlahe İllallah" (Allah’tan Başka İlah Yoktur) kelimesini kabul edip etmediğidir. Șayet kiși bunu onaylarsa mümin, inkâr ederse kafirdir. ${ }^{83}$

Allah Inancı: Allah bir tektir. Zuhurları aracılığıyla kendini insana gösterendir. Son zuhurları da Bab ve onun vekili olan Subhi Ezel'dir. ${ }^{84}$

Kitap İnancı: Bașta Bab’ın "Beyan"ı olmak üzere, ona vahyedildiği kabul edilen tüm eserlere ek olarak öncelikle "Kitab-i Nur" olmak üzere Subhi Ezel'e de vahiy yoluyla yazdırıldığına inanılan kitap ve kitapçıkların hepsi Ezeliler tarafindan kutsal kabul edilmektedirler. ${ }^{85}$

Peygamber Inancl: Hz. Muhammed'den sonra insanları uyarıcı ve onlara yol gösterici olarak Bab gelmiştir. Bab'dan iki bin sene sonrasına, yani üç binli yılların sonlarına kadar da yeni bir peygamber gelmeyecektir. Subhi Ezel ise onun tarafından açık şekilde vekil tayin edildiği için onun görevini devam ettirmiştir. ${ }^{86}$

Klyamet, Cennet ve Cehennem Inancl: Kiyamet, Cennet ve Cehennem kavramları bu zamana kadar hep yanlış anlaşılmıştır. Gerçek anlamda "Kıyamet" zuhurun ortaya çıkması, "Cennet" buna tabi olanların yaşadığı yer, "Cehennem" ise onu inkâr edenlerin yaşadığı yerdir. ${ }^{87}$

\section{b. Ameli Esaslardan Bazıları}

Ezelilere göre ibadet, kişinin halis bir niyet ve ruh ile Allah'a yönelip dua etmesidir. Bugüne kadar bilinen ve emredilen tüm ibadetler artık kalkmıştır. Onların yerine "Vahid" (Birlik) ${ }^{88}$ esasına dayalı ve on dokuz rekatlık dua seansı getirilmiştir. Bu rekatların ilk üçü "Allah'ın Birliği",

${ }^{83}$ Azal, The Religion of The Bayan and The Claims of The Baha'is, 46.

${ }^{84}$ Manuchehri, "The Primal Point's Will and Testament".

85 Şevki Efendi, Bahai Dininin I. Yüzyıll, 26.

86 Süleyman Nazif, Nasıruddin Şah ve Babiler, (Haz. A. Ergun Çınar), Kitabevi Yayınları, İstanbul 2014, s. 71.

${ }^{87}$ Azal, The Religion of The Bayan and The Claims of The Baha'is, 54

88 Babîlerin yaptıkları ebcet hesabına göre Vahid, on dokuz sayısına karşılık gelmektedir. Ayrıntılı bilgi için bk. Fığlalı, Babilik ve Bahailik, 31. 
sonraki dördü "Sıfatların Birliği", sonraki altısı "Fiilerin Birliği” ve son altısı ise "İbadetlerin Birliği" içindir. Ayrıca Ezeliler için hangi ibadet yapılırsa yapılsın İslamiyet'teki gibi bir abdest zorunluluğu yoktur. Kişinin bedeninin ve klyafetinin temiz olması yeterlidir. ${ }^{89}$

Yukarıdaki bilgiden de anlaşılacağı üzere Ezelilerde ibadet dendiğinde akla ilk gelen ritüel namazdır.

Namaz Ibadeti: Ezeliler için namazdan kasıt, dua ve "Beyan" kitabından ayetler okumaktır. Başlangıçta her biri on dokuz ayetten oluşan on dokuz surenin, yani üç yüz atmış bir ayetin günde en az bir defa okunması istenmiştir. ${ }^{90} \mathrm{Bu}$ uygulama zamanla neredeyse iki katına çıkarılmış ve günlük yedi yüz ayet okunması ya da yedi yüz defa "Allahu Azhar" (Allah Zuhur Edendir) denmesi istenmiştir. Ayrıca dua ederken dikkat edilmesi gereken en önemli hususlardan biri, bu ibadeti yaparken kişinin tek başına olması ve dizlerinin üzerine çökerek kıbleye doğru yani Bab’ın Şiraz'daki evine yönelmesidir. 91

Cenaze Namazı ve Sonrası: Namaz bireysel olarak yapılması gereken bir ibadettir ve kişinin yalnız başına kendi evinde ibadet etmesi en makbul olandır. Ezeliler için cemaat halinde topluca kılınmasına izin verilen tek namaz “Cenaze Namazı"dır (Ölü için dua etme). ${ }^{92}$ Cenaze namazı kılındıktan sonra ölen kimsenin cenazesi en az bir, en fazla dört kez yıkanmalı ve cam veya taştan bir tabut içerisine defnedilmelidir. Vefat olayının gerçekleşmesinden itibaren on dokuz gün boyunca mezar aralıksız ziyaret edilmelidir. ${ }^{93}$

Oruç İbadeti: Yaşı on bir ile kırk iki arasında olan her Ezeli, Babî yılının ilk ayı olan Nevruz'da ${ }^{94}$ on dokuz gün oruç tutmakla mükelleftir. ${ }^{95}$

Hac Ibadeti: Bab'ın Şiraz'daki evi en kutsal mekandır. Maddi durumu iyi olan Ezelilerin ömürlerinde bir defa da olsa hac için buraya gitmeleri

${ }^{89}$ Azal, The Religion of The Bayan and The Claims of The Baha'is, 50,52; Ethem Ruhi Flğlalı - Ramazan Şimșek, "Bahailik ve El-Kitabu'l Akdes (Türkçe Çeviri)", e-makalat Mezhep Araştırmaları 3/2 (Güz 2010), 18.

90 Fığlalı - Şimșek, "Bahailik ve El-Kitabu'l Akdes (Türkçe Çeviri)”, 19.

${ }^{91}$ Azal, The Religion of The Bayan and The Claims of The Baha'is, 46,52.

${ }^{92}$ Azal, The Religion of The Bayan and The Claims of The Baha'is, 46,52.

93 Bahaullah, Kitab- I Akdes (Ankara: Desen Ofset, 2003), 217.

94 Babî takvimi her biri on dokuz gün olan on dokuz aydan meydana gelmektedir. Bu aylardan ilk Nevruz'dur. Miladi takvimde 2 Mart ile 20 Mart tarihleri arasına denk gelmektedir. Ayrıntılı bilgi için bk. İpek, Yeni Bir Dini Hareket Olarak Bahailik ve Türkiye'de Bahailer, 267.

95 Azal, The Religion of The Bayan and The Claims of The Baha'is, 53; Süleyman Nazif, Nasıruddin Şah ve Babiler, (Haz. A. Ergun Çınar), Kitabevi Yayınları, İstanbul 2014, s. 56. 
gerekmektedir. Ayrıca on dokuz Hurufu Hayy'a ait olan ve "Buqa" (çoğulu Biqa) adı da verilen mezarlar ile "Maqaid" (çoğulu Maqad) adı verilen türbeler de Ezeliler için özel mekanlardır. ${ }^{96}$ Buralara ek olarak Subhi Ezel'in Kıbrıs Gazimağusa'daki türbesi de Ezeliler için önemli ziyaret yerlerinden biridir. Bunların dışında kalan türbelerin yıkılması gerekmektedir. ${ }^{97}$

Zekât İbadeti: Ezelilerin mallarının beşte birini yılda bir kez kendilerini idare eden kimselere vergi olarak vermeleri gerekmektedir. ${ }^{98}$

\section{c. Sosyal ve Ahlaki Esaslardan Bazıları}

İnanç ve ibadete dair kuralların dışında kişilerin gündelik hayatlarını da düzenleyen birtakım kurallar mevcuttur. "Beyan" kaynaklı olan bu hükümlerin genelinde insanın ve toplumun huzuru esas alınmıștır. Bunlardan yapılması tavsiye edilenlerden bazıları șu şekildedirler:

Ezeliler birbirleriyle karşılaştıklarında mutlaka selamlaşmalıdır. Selam verirken "Allahu Ekber", selam alırlarken de "Allahu Azam" denmelidir. ${ }^{99}$

Her Ezeli evlenmek zorundadır Kız çocukları on bir yaşından sonra evlendirilebilirler. Eşin rızası olmak şartıyla aynı anda en fazla iki eşle evli olunabilir. Eşlerden biri ölürse geride kalan erkek doksan beş gün sonra, kadınsa doksan gün sonra yeniden evlenebilir. Şayet eşler anlaşamıyorlarsa boşanmalarında bir sakınca yoktur. Sadece bu kararı aldıklarında bir yıl beklemeleri gerekmektedir. ${ }^{100}$

Her Ezeli on dokuz günde bir, on dokuz Ezeli'yi su ikram ederek dahi olsa evinde konuk etmelidir. ${ }^{101}$

"Beyan"ı daha iyi anlayabilmek için ilim sahibi olmak ve bilimin her alanıyla ilgilenmek zorunludur. ${ }^{102}$

Kimse inancından dolayı dışlanamaz ve değiştirmesi için zorlanamaz. Ezeli olmayan insanlarla sosyal münasebette bulunulmasında ve alışveriş yapılmasında hiçbir sakınca yoktur. ${ }^{103}$

${ }^{96}$ Azal, The Religion of The Bayan and The Claims of The Baha'is, 47.

97 Süleyman Nazif, Nasıruddin Șah ve Babiler, (Haz. A. Ergun Çınar), Kitabevi Yayınları, İstanbul 2014, s. 70.

98 Fı̆̆lalı - Șimșek, "Bahailik ve El-Kitabu'l Akdes (Türkçe Çeviri)”, 18.

${ }^{99}$ Azal, The Religion of The Bayan and The Claims of The Baha'is, 54; Süleyman Nazif, Nasıruddin Şah ve Babiler, (Haz. A. Ergun Çınar), Kitabevi Yayınları, İstanbul 2014, s. 55. 100 Azal, The Religion of The Bayan and The Claims of The Baha'is, 53; Süleyman Nazif, Nasıruddin Şah ve Babiler, (Haz. A. Ergun Çınar), Kitabevi Yayınları, İstanbul 2014, s. 56. ${ }^{101}$ Frğlalı - Şimşek, “Bahailik ve El-Kitabu'l Akdes (Türkçe Çeviri)”, 19.

102 Azal, The Religion of The Bayan and The Claims of The Baha'is, 60.

103 Azal, The Religion of The Bayan and The Claims of The Baha'is, 50-51. 
Kişisel hijyen için sık sık banyo yapılmalı, saçlar taranmalı, tırnaklar kesilmeli ve düzenli olarak vücut temizliği yapılmalıdır. 104

Allah'ın yarattığı hiçbir şey pis olamaz. Bu sebeple İslam'ın pis saydığı şeyler de dahil olmak üzere bir Ezeli için Allah'ın yarattığı her şey temiz kabul edilir. 105

Kişinin ve toplumun menfaati için yapılması istenen bu davranışların dışında yine aynı gerekçelerle yapılması istenmeyen hatta yasaklanan bazı davranışlarda vardır. Bunlar:

Sigara, alkol, uyuşturucu madde gibi kişiye zarar veren şeyleri kullanmak ve satmak, kumar oynamak ve oynatmak, zina yapmak ve yaptırmak, dilenmek ve dilenene yardım etmek, savaş zamanı dışında silah taşımak haramdır. 106

Adam öldürmek ve can yakmak en büyük günahlardan kabul edilir. Bu sebeple suçu ne olursa olsun ölüm cezası vermek, anne baba ile evladı arasında dahi olsa bir başkasını fiziksel olarak cezalandırmak yasaktır. Kişilere verilebilecek tek ceza ya para cezası ya da eşiyle beraber olmasını engellemektir. ${ }^{107}$

\section{Bahailere Göre Mirza Yahya ve Ezeliler}

Mirza Yahya, Bahailiğin kurucusu olan Bahaullah Mirza Hüseyin Ali'nin kardeşi olmasına rağmen hayatı boyunca en büyük mücadeleyi ona ve onun taraftarlarına karşı vermiştir. Tabii ki bu çatışmanın diğer tarafında olan Bahaullah içinde aynı durum söz konusudur. Bahaullah'ta dahil olmak üzere Bahailere göre Mirza Yahya; "Nakısı Ekber", "Bab’ın Misakının Baş Nakısı", "Şerrin ve Açgözlülügün Yaşayan Örneği", "Seyyid Muhammed İsfehani'nin Kuklası", "Sırf Kendi Çıkarları İçin Bab'ın Yazdıklarını Değiștiren", "Menfaati Uğruna Kendisi Dışındaki Babîliğin Aynalarını Ölüme Mahkûm Ettiren”, “Hasetinden Dolayı Deyyan'ın ve Bab'ın kuzeni Mirza Ali Ekber'in Ölümüne Sebep Olan”, "Bab'ın Mirasını Beş Paralık Eden” bir insandir. 108

Bahaullah kaleme aldığı (Allah tarafından kendisine yazdırıldığını iddia ettiği) birçok eserinde kardeşi Mirza Yahya'nın durumuna değinmiştir.

104 Azal, The Religion of The Bayan and The Claims of The Baha'is, 51.

105 Flğlalı - Şimşek, "Bahailik ve El-Kitabu'l Akdes (Türkçe Çeviri)”, 18.

106 Azal, The Religion of The Bayan and The Claims of The Baha'is, 50,52; Flğlalı - Şimșek,

"Bahailik ve El-Kitabu'l Akdes (Türkçe Çeviri)", 39.

107 Azal, The Religion of The Bayan and The Claims of The Baha'is, 50.

108 Bahaullah - Abdulbaha, Kutsal Vasiyetnameler (İstanbul: Bahai Eserleri Basım Dağıtım, 
Örneğin “Akdes Kitabı”nda kendisine yapmış olduğu birçok kötülüğe ve sonrasında yaşanan büyük acılara rağmen şayet kardeşi yaptıklarından pişman olur ve dönerse Allah'ın onu bağışlayacağının teminatını vermiştir. ${ }^{109}$ Aynı şekilde "Hevdec (Samsun) Levhi" ve "Kurdunoğlu (İbni Zib) Risalesi"nde, "Beyan Ehli" dediği Mirza Yahya ve tabiilerinden; isyankarlar, yoldan çıkmışlar, gece gündüz terbiye edilmeye çalışılmasına rağmen başarısız olunanlar, hakikati göremeyen körler diye bahsetmiş ve onların kendisine ve Emir'e verdiği büyük zararları anlatmıştır. ${ }^{110}$

Bahai hiyerarşisinde Bahaullah'tan sonra gelen Abdulbaha vasiyetnamesinde Mirza Yahya ve taraftarlarını yanlış yolda olan hain, isyankâr insanlar diye nitelemiş ve onların nakıs olduklarını belirtmiştir.111 Torunu Şevki Efendi ise 1844 yılında Bab ile başlayıp 1944 yılına kadar geçen süreçte Babîlik ve Bahailiğin tarihini anlattığı yirmi beş bölümden oluşan "Bahai Dininin I. Yüzyılı" adlı kitabının birçok yerinde Mirza Yahya ve taraftarlarını hain ilan etmiş ve onların Emir'e verdikleri zararlardan bahsetmiştir. ${ }^{112}$

Günümüzde de Bahailer için Mirza Yahya ve Ezeliler konusunda konuşmak, pek hoş karşılanmamakta ve bu konuda olumlu ya da olumsuz şeklide de olsa fikir beyan edilmemektedir.

\section{Sonuç}

Subhi Ezel ve Ezelilik konusuna dair literatürde çok az sayıda çalışma yapılmış olması ve yapılan çalışmalarında Ezelilerin en büyük rakibi olan Bahailer tarafından hazırlanmış olması ister istemez verilerin güvenilirliği meselesini akla getirmektedir. Bizde bu ihtimali en az indirgeyebilmek için Ezeli referanslı ya da onlar tarafından da objektifliği kabul edilen kaynaklarla bir sağmama yapmaya çalıştık.

Şii İslam anlayışının "Beklenen Kurtarıcı" fikrinin son örneklerinden biri olan Bab'ın söylemleri o dönemde İran coğrafyasında hâkim olan Kaçar Hanlığında çok sayıda insanın ilgisini çekmiştir. Kendilerine Babî adı verilen bu insanların sayının artmasıyla doğru orantılı olarak Kaçar halkı içinde onların söylem ve fiillerine karşı gelişen tepkide artmıştır. Gerek Bab'ın İslam akaidine ters düşen söylemleri gerekse Babîlerin ülke genelinde sebep oldukları asayiş olayları Kaçar idaresi tarafından Bab’ın idam edilmesiyle

109 Șevki Efendi, Bahai Dininin I. Yüzyılı, s. 224.

110 Bahaullah, Kurdun Oğlu Risalesi, çev. Mecdettin İnan (İstanbul: Özdemir Basımevi, 1976), 26,32,55.

111 Bahaullah - Abdulbaha, Kutsal Vasiyetnameler, 7-30.

112 Şevki Efendi, Bahai Dininin I. Yüzyılı, (Ter. Suna Bozkır), Baha Yayınları, İstanbul 1995. 
çözülmeye çalışılmıştır. Fakat umulanın aksine bu çözüm yolu işleri daha da karıştırmıştır. Bab sonrası ortada kalan Babîlerin liderliği için "Subhi Ezel" Mirza Yahya ve "Bahaullah" Mirza Hüseyin Ali adlı iki kardeş arasında başlayan iktidar mücadelesiyle kısa sürede taraftarlarına da yansımıştır.

Bab'ın vekilliği için yaşana bu çekişme Babî toplumunda gruplaşmalara ve neticesinde bölünmelere sebep olmuştur. Bu rekabet zaman içinde çatışmaları da beraberinde getirmiştir. Babîler için temel sorun "Bab'ın vekilinin kim olduğu?" sorusu olmuştur. Bu noktada, kaynakların büyük çoğunluğu Subhi Ezel'i işaret etmekteyse de taraflar konuyu farklı yaklaşım tarzlarıyla ele aldıkları için ortak bir noktada buluşamamışlardır.

Başlangıçta Şia'da beklenen kurtarıcı fikriyle ortaya çıkan Babîlik zaman içerisinde Bab'ın kendisini Allah'ın yeryüzündeki yansıması ve peygamberi olarak görmesi, İslam şeriatı da dahil olmak üzere geçmiş tüm şeriatları kaldırdığını beyan edip yeni bir din getirdiğini haber vermesiyle apayrı bir kimlik kazanmıștır. Subhi Ezel de onun bu fikirlerini alıp daha da ileri götürmüştür. İslami bir akım olarak ortaya çıkıp kısa sürede dine dönüştügü iddia edilen bu oluşum zaman içerisinde kendi inanç, ibadet ve ahlak ilkelerini de oluşturmuştur. Bunu yaparken de Bab'a vahyedildiğine inandıkları "Beyan" kitabını ve onun tamamlayıcısı olarak gördükleri Subhi Ezel'e ait eserleri kendileri için ana kaynak olarak kabul etmişlerdir.

Günümüzde Babî inancı temelli üç farklı oluşum mevcuttur. Bunlar; Subhi Ezel'e tabii olanların oluşturduğu ve çoğunluğunu İran'da yaşayanların oluşturduğu, sayısı birkaç binle ifade edilen "Ezeliler", Bahaullah'a tabii olanların oluşturduğu ve günümüzde dünyanın birçok bölgesinde mensubu olan "Bahailer", son olarak da bu iki gruba da dahil olmayıp Bab'tan sonra bir vekil kabul etmeyenlerin oluşturduğu ve tamamına yakını İran'da yaşayan az sayıdaki “Beyani Babîler"dir.

Ezeliliğin kurucusu olan Subhi Ezel ömrünün son günlerini geçirdiği Kıbrıs'ta o güne kadar savunduğu tüm iddialarını dillendirmekten vazgeçip münzevi bir hayat tarzını seçmiştir. Onun bu pasif tavrı kendinden sonraki aile üyelerine de sirayet etmiş ve torunlarından birkaçı dışında ailesinden dahi Ezeli olanlar neredeyse kalmamıştır. Hatta onlar kendilerini Ezeli soyundan geldiklerini kabul etmekle birlikte Ezeliliği bir din değil bir kültür olarak görmektedirler. Bu cümlede Ezeliliğin günümüzdeki durumunu açıkça ifade etmektedir.

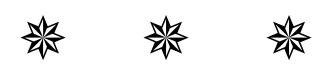


Yasin İPEK

\section{Beyanname:}

\section{Etik Kurul İzni:}

Etik Kurul İzni gerekmemektedir.

\section{Katkı Oranı Beyanı:}

Yazar, makaleye başkasının katkıda bulunmadığını beyan etmektedir.

\section{3. Çıkar Çatıșması Beyanı:}

Yazar, herhangi bir çıkar çatışması olmadığını beyan etmektedir.

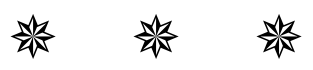

\section{KAYNAKÇA}

ABDUBAHA. A Traveler's Narrative Written to Illustrate the Episode of The Bab. trans. Edward G. Browne. Wilmette: Bahai Publishing Trust, 1980.

AYDOĞAN, Bedri. "Namık Kemal'in Magosa Sürgünlüğü". Çukurova Üniversitesi Sosyal Bilimler Enstitüsü Dergisi 12/12 (Eylül 2003), 1528.

AZAL, Jalal S. The Religion of The Bayan and The Claims of The Baha'is. PDF: Bayanic Digital Publications, January 2004.

BAHAULLAH - ABDULBAHA. Kutsal Vasiyetnameler. İstanbul: Bahai Eserleri Basım Dağıtım, 2011.

BAHAULLAH. Hz. Bahaullah'ı́n Levihleri. çev. Mecdi İnan. İstanbul: Menteş Matbaası, 1994.

BAHAULLAH. Kitab-ı Akdes. Ankara: Desen Ofset, 2003.

BAHAULLAH. Kurdun Oğlu Risalesi. çev. Mecdettin İnan. İstanbul: Özdemir Basımevi, 1976.

BALYUZI, Hasan M.. Bahaullah, King of Glory. Oxford: George Ronald Publishing, 2000.

BARRET, David V. The New Believers. London: Cassell \& Co, 2001.

BLOCHET, Edgar. "A Preliminary List of The MSS of The Works of Șubh-i Azal Held at The Bibliotheque Nationale of Paris", trans. Wahid Azal, Catalogue Des Manuscrits Persans De La Bibliotheque Nationale. 4/315. Berlin: 2015.

BROWNE, Edward G.. A Traveller's Narrative. Amsterdam: Philo Press, 1975.

BROWNE, Edward G.. "Babism". Religious Systems of The World: A 
Contribution to the Study of Comparative Religion. 333-353. London: Swann Sonnenschein, 1890.

BROWNE, Edward G.. "Personal Reminiscences of The Babi Insurrection at Zanjan in 1850". Journal of The Royal Asiatic Society 29/4 (October 1897), 761-827. https://doi.org/10.1017/S0035869X00025004

BARRET, David V.. The New Believers. London: Cassell \& Co, 2001.

BROWNE, Edward G.. Materials for the Study of the Babi Religion. Cambridge: Cambridge University Press, 1918.

BUFTON, Nigel. Mirza Abbas Buzurg Nuri. Or Yehuda: MyHeritage Company, 2008.

CARUS, Paul. "A New Religion. Babism". The Open Court. 13/355-373. Chicago: The Open Court Publishing, 1904.

COLE, Juan R. I.. "The Azali- Bahai Crisis of September 1867". Studies in Modern Religions. ed. Moshe Sharon. 227-251. Leiden: E. J. Brill, 2004.

FIĞLALI, Ethem Ruhi - Şimşek, Ramazan. "Bahailik ve El-Kitabu'l Akdes (Türkçe Çeviri)”. e-makalat Mezhep Araștırmaları 3/2 (Güz 2010), 7144.

FIĞLALI, Ethem Ruhi. Babilik ve Bahailik. Ankara: Türkiye Diyanet Vakfı Yayınları, 1994.

HATAY, Mete. "Kıbrıs'ta Yaşayan Son Ezeliler". Nehaberkibris. Erişim 1 Nisan 2021. http://www.nehaberkibris.com/haber/kibrisda-yasayan-sonezeliler/3208/

HATAY, Mete. "Suphi Ezel'in Cenaze Töreni ve Sonrası". Havadiskibris. Erişim 1 Nisan 2021. https://www.havadiskibris.com/suphi-ezelin-cenazetorenini-sonrasi/

IPEK, Yasin. "Alevilikteki Düşkünlük ile Bahailikteki Tard Anlayışının Mukayesesi". Route Educational and Social Science Journal 6/8 (September 2019), 170-179. https://doi.org/10.17121/ressjournal.2273

İPEK, Yasin. İran'da Kaçar Türk Hanedanlığı- Babilik ve Bahailik. İstanbul: Ekim Yayınları, 2010.

IPEK, Yasin. Yeni Bir Dini Hareket Olarak Bahailik ve Türkiye'de Bahailer. Kayseri: Kimlik Yayınları, 2020.

KARADENIZ, Yılmaz. İran'da Sömürgecilik Mücadelesi ve Kaçar Hanedanı. İstanbul: Bakış Yayınları, 2006.

KASHANI, Jani. Kitab-i Nuqtat al-Kaf: Being the Earliest History of The Babis. 
ed. Edward G. Browne. Leiden: E. J. Brill, 1910.

LUKACH, Harry Charles. The Fringe of the East; A Journey Through Past and Present Provinces of Turkey. Warszawy: Wentworth Press, 2019.

MACEOIN, Denis. "Azali Babism". Encyclopaedia Iranica. 3/179-181. New York: Columbia University Publishing, 1989.

MACEOIN, Denis. "Divisions and Authority Claims in Babism (1850-1866)". Studia Iranica 18/1 (1989), 93129. https://doi.org/10.2143/SI.18.1.2014576

MANUCHEHRI, Sepehr. "The Primal Point's Will and Testament". Research Notes in Shaykhi, Babi and Bahai Studies 7/2 (September 2004). https://www.h-net.org/ bahai/notes/vol7/BABWILL.htm

MC CANTS, William - Milani, Kavian. "The History and Provenance of an Early Manuscript of The Nuqtat al-kaf Dated 1268". Iranian Studies 37/3 (2004), 431-449. https://doi.org/10.1080/0021086042000287523

MILLER, William M. The Baha'i Faith: Its History and Teachings. Pasadena: William Carey Publishing, 1974.

MOMEN, Moojan. "Mirza Yahya". The Bahai Encyclopedia. Evanston: National Spiritual Assembly of The Baha'is of The United States Publishing, 2009.

ÖZKAYA, Süleyman. Osmanlı Arşiv Belgeleri Işı̆̆ında Bahailik Hareketi. İzmir: Akademi Kitabevi, 2000.

RUHİ, Atiyya. "A Brief Biography of His Holiness Subh-i Azal". Bayanic. Erişim $10 \quad$ Mayıs 2021. https://www.bayanic.com/lib/typed/hist/AzalHist/Subh-bioEng.htm.

SMITH, Peter. A Concise Encyclopedia of the Baha'i Faith. Oxford: Oneworld Publications, 2000.

ŞEVKİ EFENDİ. Bahai Dininin I. Yüzyılı. çev. Suna Bozkır. İstanbul: Baha Yayınları, 1995.

TAHERZADEH, Adip. Hz. Bahaullah'ı́n Zuhuru. çev. Süreyya Güler. Cilt 1. İstanbul: Kazancı Matbaacılık, 1995.

TAHERZADEH, Adip. Hz. Bahaullah'ın Zuhuru. çev. Süreyya Güler. Cilt 2. İstanbul: Kazancı Matbaacılık, 1998.

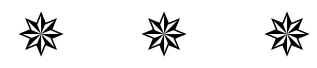




\title{
SUBHI AZAL MIRZA YAHYA AND THE AZALIS
}

\author{
Yasin İPEKa
}

\section{Extended Abstract}

Established by the Turks, the Qajar Dynasty was a dominant state in Iranian geography between 1795 and 1925. The Babism movement, which emerged in the 1850s, caused great troubles for the Qajars, where many internal and external disturbances were experienced for a hundred and thirty years. With the protection of foreign powers, especially Russia, and the support of different religious segments within the country, Babism spread to the whole country in a short time.

Babism is a religious movement of Shia Islamic origin that started with the appearance of Mirza Ali Muhammad in Shiraz in 1844, claiming that he was the gateway to the anticipated savior in Shia (Bab). But Bab Mirza Ali Muhammad, who gained many supporters in a short time, started to claim that he received revelation by changing his discourse. According to some sources, Bab, who claimed that he was a prophet and even the image of God on earth, was arrested due to the discomfort caused by these discourses and the anarchist attitudes of the Babis who he led. During his imprisonment, Bab, who kept in touch with his supporters, sensed the danger of the disintegration of the Babis who were left without a leader, and appointed a deputy for him. The beginning of Azalis, which is our subject, is based on this reason.

The person chosen as deputy by Bab is Mirza Yahya, who is only eighteen years old. Mirza Yahya was one of the first people to believe in the Bab, who belonged to one of the noble families of Iran. From the day he was appointed as a deputy, he preferred to use the nickname "Subhi Azal (Eternity Morning)", which Bab found suitable for him. In the struggle for the leadership of the Babis, Mirza Yahya's biggest rival was Mirza Huseyn Ali, his half-brother. Mirza Huseyn Ali, who did not recognize the leadership of Subhi

\footnotetext{
a Asst. Prof., Kayseri University, yasinipek@kayseri.edu.tr
} 
Azal, whom Bab clearly pointed out, and his supporters did not swear allegiance to him and accused him of fraud. The power struggle between the two brothers not only affected the Babis society but also disturbed the Qajar people. This situation was also added to the rebellions caused by the Babis in many regions of the country after the Bab was executed in 1850. Afterwards, they attempted to assassinate Qajar ruler Nasiruddin Shah. As a solution to this, the Qajar administration deported these people.

As a result of the negotiations with the Ottoman Empire, the prominent and distressed ones of the Babis were exiled to Baghdad in 1853. Subhi Azal, who is not among those who will be exiled, secretly joins the caravan and goes to Baghdad, worrying that he will share the same fate with Bab if he stays in Iran. Subhi Azal, who attracted respected Babis like Sayyed Muhammad of Isfahan, managed to gather many people around him in a short time. When the dose of the struggle with his brother started to disturb the local people with each passing day, the Ottoman administration sent them into exile to Istanbul in 1863. During their departure from Baghdad, Mirza Huseyn Ali announces to the people that he is the person who informed the arrival of Bab. Subhi Azal, who says that his brother made Bab as an instrument to his lies to come to the fore, declares that he broke off his relationship with him.

The person Bab has chosen as his deputy is Mirza Yahya, who is only eighteen years old. Mirza Yahya was one of the first people to believe in the Bab, who belonged to one of the noble families of Iran. From the day he was appointed as a proxy, he preferred to use the nickname "Subhi Azal", which Bab found suitable for him. In the struggle for the leadership of the Babis, Mirza Yahya's biggest rival was Mirza Huseyn Ali, his half-brother. Mirza Huseyn Ali, who did not recognize the leadership of Subhi Azal, whom Bab clearly pointed out, and his supporters did not swear allegiance to him and accused him of fraud. The power struggle between the two brothers not only affected the Babis society but also disturbed the Qajar people. When the rebellions caused by the Babis in many regions of the country after the execution of the Bab in 1850 and the last attempt to assassinate the Qajar ruler Nasiruddin Shah, the Qajar administration found the solution to deport them.

Before the Babis themselves, their bad reputation reaches Istanbul. Taking into account the suggestions of the Qajar authorities, the Ottoman administration took them to Edirne after a few months. Because the Ottoman administration considered that the presence of such an objectionable community in the capital of the country colud have negative consequences. The size of the struggle between the brothers change in Edirne. Now they 
even attempted to poison and killed each other. This brutal struggle of the leaders was also reflected in the grassroots. The divergence between the Babis became completely clear in March 1868, when Mirza Huseyn Ali declared himself "Bahaullah (God's Light)" and the "Order". Now the Babis are divided into three groups. The first is Subhi Azal and "Azalis", who stated that he was openly appointed by Bab. The second is the Bahaullah who claims to be the savior that Bab has reported. The third one is the "Bayani Babis", who think that both brothers betrayed the Bab for their own ambitions and were not subject to anyone. Subhi Azal was uncomfortable with this split. He took action both to secure himself and to eliminate the Bahaullah threat completely by strengthening his relations with local administrators and getting their support. However, his plan backfires and the Ottoman administration, which is already uncomfortable with the Babis, makes more uneasy. A detailed report about the Babis is prepared by the delegation formed by the order of the Ottoman Sultan Abdulaziz. In this report, it was stated that the Babis, especially Subhi Azal and Bahaullah, claimed that they received revelation and wrote books similar to the Quran. It was also emphasized that they should be punished severely because they abused people's religious feelings by introducing themselves as prophets. Based on the information in this report, Sultan Abdulaziz sent Subhi Azal and his family to Famagusta in Cyprus, and Bahaullah and his family to Akka in Palestine, under fortress imprisonment for life with the edict of 11 July 1868.

Subhi Azal, who arrived in Cyprus in August 1868, gave up all his claims and statements and retreated after this punishment. Subhi Azal, of whom a limited number of people in Cyprus has information about his past, has been accepted by the people as a reputable Shiite cleric. Since he did not have a specific job and income, he had great financial difficulties. The British, who took over the administration of Cyprus in 1878, first revoked Subhi Azal's conviction and liberated him, and then relieved his financial difficulties by paying him a salary. When he passed away in 1912, there were very few Azalis around him apart form his family only and he was buried in Famagusta according to Islamic traditions. His grave, which was turned into a tomb still exists today. This tomb, which is open to the visits of Babis and Azalis coming from different countries, especially Iran, is among the places considered sacred for the Azalis.

The Azalis, who have their own principles of belief, worship and morality, derive the principles regarding these from the book "Declaration", which they believe was revealed to the Bab. In addition, they regard the works written by Subhi Azal and which they believe to have been dictated by Allah 
Yasin İPEK

as a kind of interpretation of the Bayan and regard them as sacred.

Today, with the most optimistic estimation, it is assumed that the Azalis have a population of around five thousand and the majority live in Iran. Unlike the Babis, who are their biggest rivals, they do not have a religious leader or an institutionalized structure.

Keywords: History of Religions, Subhi Azal, Babis, Azalis, Bahais.

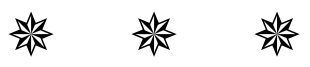

\section{Declarations:}

\section{Ethics approval:}

Not applicable.

\section{Author contribution:}

The author declares no one has contributed to the article.

\section{Competing interests:}

The author declares no competing interests.

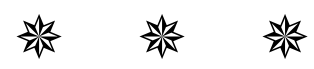

